OPEN ACCESS

Edited by: Kasper Elgetti Brodersen, University of Copenhagen, Denmark

Reviewed by:

Mikael Kim

University of Technology Sydney,

Australia

Nadine Schubert,

University of Algarve, Portugal

*Correspondence:

Pimchanok Buapet

pimchanok.b@psu.ac.th

Specialty section

This article was submitted to

Marine Ecosystem Ecology,

a section of the journal

Frontiers in Marine Science

Received: 31 August 2021

Accepted: 06 October 2021

Published: 26 October 2021

Citation:

Yucharoen $M$, Sinutok $S$

Chotikarn P and Buapet P (2021)

Experimental Assessment

of Vulnerability to Warming in Tropical

Shallow-Water Marine Organisms.

Front. Mar. Sci. 8:767628

doi: 10.3389/fmars.2021.767628

\section{Experimental Assessment of Vulnerability to Warming in Tropical Shallow-Water Marine Organisms}

\author{
Mathinee Yucharoen ${ }^{1,2,3}$, Sutinee Sinutok ${ }^{1,2}$, Ponlachart Chotikarn ${ }^{1,2,3}$ and \\ Pimchanok Buapet ${ }^{2,4 *}$ \\ ${ }^{1}$ Faculty of Environmental Management, Prince of Songkla University, Hat Yai, Thailand, ${ }^{2}$ Coastal Oceanography \\ and Climate Change Research Center, Prince of Songkla University, Hat Yai, Thailand, ${ }^{3}$ Marine and Coastal Resources \\ Institute, Faculty of Environmental Management, Prince of Songkla University, Hat Yai, Thailand, ${ }^{4}$ Division of Biological \\ Science, Faculty of Science, Prince of Songkla University, Hat Yai, Thailand
}

Tropical shallow-water habitats represent the marine environments with the greatest biodiversity; however, these habitats are the most vulnerable to climate warming. Corals, seagrasses, and macroalgae play a crucial role in the structure, functions, and processes of the coastal ecosystems. Understanding their growth and physiological responses to elevated temperature and interspecific sensitivity is a necessary step to predict the fate of future coastal community. Six species representatives, including Pocillopora acuta, Porites lutea, Halophila ovalis, Thalassia hemprichii, Padina boryana, and Ulva intestinalis, collected from Phuket, Thailand, were subjected to stress manipulation for 5 days. Corals were tested at $27,29.5,32$, and $34.5^{\circ} \mathrm{C}$, while seagrasses and macroalgae were tested at $27,32,37$, and $42^{\circ} \mathrm{C}$. After the stress period, the species were allowed to recover for 5 days at $27^{\circ} \mathrm{C}$ for corals and $32^{\circ} \mathrm{C}$ for seagrasses and macroalgae. Non-destructive evaluation of photosynthetic parameters $\left(F_{\mathrm{v}} / F_{\mathrm{m}}, F_{\mathrm{v}} / F_{0}, \phi \mathrm{PS} I \mathrm{l}\right.$ and rapid light curves) was carried out on days $0,3,5,6,8$, and 10. Chlorophyll contents and growth rates were quantified at the end of stress, and recovery periods. An integrated biomarker response (IBR) approach was adopted to integrate the candidate responses ( $F_{\mathrm{v}} / F_{\mathrm{m}}$, chlorophyll content, and growth rate) and quantify the overall temperature effects. Elevated temperatures were found to affect photosynthesis, chlorophyll content, and growth rates of all species. Lethal effects were detected at $34.5^{\circ} \mathrm{C}$ in corals, whereas adverse but recoverable effects were detected at $32^{\circ} \mathrm{C}$. Seagrasses and macroalgae displayed a rapid decline in photosynthesis and lethal effects at $42^{\circ} \mathrm{C}$. In some species, sublethal stress manifested as slower growth and lower chlorophyll content at $37^{\circ} \mathrm{C}$, while photosynthesis remained unaffected. Among all, T. hemprichii displayed the highest thermotolerance. IBR provided evidence that elevated temperature affected the overall performance of all tested species, depending on temperature level. Our findings show a sensitivity that differs among important groups of tropical marine organisms inhabiting the same shallow-water environments and highlights the importance of integrating biomarkers across biological levels to assess their vulnerability to climate warming.

Keywords: climate change, temperature sensitivity, coral, seagrass, macroalgae, coastal habitats, tropical, Thailand 


\section{INTRODUCTION}

Temperature is one of the key factors that control cellular metabolisms and physiological performance of most marine organisms and consequently affect their growth and survival (Madeira et al., 2018; Savva et al., 2018; Dias et al., 2020). Climate warming and extreme climate events (ECEs) have been identified as among the key drivers of the structural and functional shift of the coastal ecosystems across different bioregions (Smale et al., 2019; Strydom et al., 2020). An increase of more than $1^{\circ} \mathrm{C}$ in sea surface temperature over the past century has been recorded in the tropical latitudes and even a more rapid increase has been predicted for the next century (Hoegh-Guldberg et al., 2018). Tropical shallow-water marine organisms experience great temporal variability in temperature that is largely influenced by solar radiation and tidal cycles in their natural habitats; temperatures above $40^{\circ} \mathrm{C}$ have been recorded during spring tides in seagrass meadows (Collier and Waycott, 2014; George et al., 2018), whereas shallow-water coral reefs may experience a temperature up to $34^{\circ} \mathrm{C}$ (Palumbi et al., 2014). As their surrounding temperature is already reaching their upper thermal threshold, these organisms are particularly susceptible to heat stress due to climate warming and ECEs (Stuart-Smith et al., 2017; Vinagre et al., 2019; Rasmusson et al., 2021). Although acclimation is possible, it may not be fast enough to keep up with the accelerating pace of climate change for most organisms (Collier et al., 2017; Hoegh-Guldberg et al., 2018).

Corals, seagrasses, and macroalgae play critical roles in the structure, functions, and processes of marine ecosystems in shallow areas. They serve as primary producers and habitat builders while providing invaluable ecosystem services, such as provisioning and climate change mitigation (Henderson et al., 2019; Good and Bahr, 2021). Since the 1980s, an alarming decline of these ecosystems has been recorded to be $27 \%$ of coral reefs (Cesar et al., 2003) and 35\% of the seagrass beds (Waycott et al., 2009), including vast macroalgal coverage areas (Wernberg et al., 2019) that have been lost globally. Heat stress has been found to exacerbate the degradation of marine ecosystems as evidenced by widespread coral bleaching and mortality (Eakin et al., 2019) and the extensive seagrass die-offs during 20142017 global heatwaves (Strydom et al., 2020). Responses to thermal stress in these groups of marine species depend on the duration, degree of warming, frequency of the warming event, interspecific variations, and interactions with other environmental factors. Further, these responses are manifested at different biological organization levels (Freeman et al., 2013; Collier and Waycott, 2014; George et al., 2018). Slower growth, changes in phenology, and lower reproductive output have been reported in corals, seagrasses, and macroalgae (Cantin and Lough, 2014; Hughes et al., 2019; Marín-Guirao et al., 2019; Román et al., 2020), whereas the effects on coral and its symbiotic relationship were often revealed as bleaching phenomenon (Robison and Warner, 2006; Hill et al., 2011). It is assumed that physiological acclimation may, to some extent, constitute the ability of thermotolerance and that physiological responses may precede the effects on growth and reproduction (Duarte et al., 2018; Gibbin et al., 2018; Jurriaans and Hoogenboom, 2020).
Photosynthesis, a fundamental energy process, is highly sensitive to temperature. Therefore, photosynthetic parameters have been widely used to detect thermal stress (Robison and Warner, 2006; Sinutok et al., 2012; Collier and Waycott, 2014; Rasmusson et al., 2020, 2021; Danaraj et al., 2021). Accumulating evidence has revealed that heat stress lowers the overall photosynthetic efficiency of marine photosynthetic organisms by inhibiting the photosystems, electron transport chain, and carbon fixation (Robison and Warner, 2006; Sinutok et al., 2012; Collier and Waycott, 2014; Rasmusson et al., 2020; Danaraj et al., 2021). Impaired photosynthesis can potentially affect their carbon balance and resource allocation, which, in turn, affects their growth and survival (Tremblay et al., 2016; Collier et al., 2017).

Under the ocean warming scenarios, the vulnerability of marine species, particularly the key habitat builders, to elevated temperature should be closely monitored and managed (Guan et al., 2020; Nguyen et al., 2021). Although comparative studies are scarce, the sensitivity of tropical shallow-water marine organisms to heat is expected to vary among species, life-traits (pioneer vs. climax species), life-forms (calcified vs. non-calcified species), and functional groups (Kilminster et al., 2015; Kram et al., 2016; Anton et al., 2020; Dove et al., 2020). Differences in sensitivity among corals, seagrasses, and macroalgae may be attributed to different ecological and physiological strategies as well as local adaptation (Kilminster et al., 2015; Kram et al., 2016; Savva et al., 2018; Anton et al., 2020; Dove et al., 2020). In this regard, comparative studies on the response of different species with different life-traits or life-forms from different functional groups are needed for the identification of the sensitive species and the prediction of ecosystem structural and functional shift facing climate warming.

This study aimed to establish a comprehensive understanding of the vulnerability of shallow-water marine organisms to warming in a tropical region. We evaluated the effects of increasing temperatures in species representatives of corals (Pocillopora acuta and Porites lutea), seagrasses (Halophila ovalis and Thalassia hemprichii), and macroalgae (Padina boryana and Ulva intestinalis), which are commonly found in shallow habitats in Phuket Province, Thailand. The changes in physiological performances and growth of these marine organisms were examined across the thermal range recorded in their habitats at present and in future scenarios. We further applied the integrated biomarker response index (IBR) approach to elucidate the overall impacts of warming on all the tested species. The results obtained in this study can provide insights on how to prioritize management efforts in mitigating the effects of warming in tropical shallow-water marine ecosystems. This study also provides a valuable tool to support ecological risk assessment in the context of global climate change.

\section{MATERIALS AND METHODS}

\section{Sampling and Acclimation of Biological Materials}

All biological materials were collected from Phuket, Thailand from May to June 2019. The location map of the sampling sites 
is indicated in Figure 1A. Marine species belonging to three groups of photosynthetic organisms, including corals, seagrasses, and macroalgae, were selected based on their dominance in the shallow areas of the sampling sites, which makes them more susceptible to warming and consequently relevant candidates for this study. The recorded annual sea surface temperature (SST) of Phuket, Thailand from 2017 to 2020 ranges from $27.45^{\circ} \mathrm{C} \pm 0.02^{\circ} \mathrm{C}$ to $32.00^{\circ} \mathrm{C} \pm 0.02^{\circ} \mathrm{C}$ (Figure 1B).

The corals $P$. acuta and $P$. lutea and the lightly-calcified macroalga $P$. boryana were collected from Panwa, Phuket $\left(7^{\circ} 48^{\prime} 6.26^{\prime \prime} \mathrm{N} 98^{\circ} 24^{\prime} 23.75^{\prime \prime} \mathrm{E}\right)$. Healthy colonies of $P$. acuta and $P$. lutea were collected from 3 to $5 \mathrm{~m}$ depth using a stainless bone cutter, chisel, and hammer. Thalli of $P$. boryana with holdfast intact were hand-picked haphazardly at the sandflat areas at low tide and placed in plastic bags containing the seawater collected on site. The seagrasses $H$. ovalis and T. hemprichii and the macroalga $U$. intestinalis were collected from Pakhlok subdistrict, Phuket $\left(8^{\circ} 01^{\prime} 18.3^{\prime \prime} \mathrm{N} 98^{\circ} 24^{\prime} 47.2^{\prime \prime} \mathrm{E}\right)$. Monospecific patches of seagrass located at least $5 \mathrm{~m}$ apart with similar density were chosen. Intact plants (leaves and root/rhizome complex) with their sediment were collected using a hand shovel, placed in plastic boxes, and covered with wet paper towels. Thalli of $U$. intestinalis, free-floating green tides-forming macroalgae, that are found in the seagrass meadow were hand-picked at low tide and kept in plastic bags containing the seawater collected on the site. All biological materials were transferred with natural seawater to the aquarium facility of the Coastal Oceanography and Climate Change Research Center (COCC), Prince of Songkla University within $12 \mathrm{~h}$ of collection. Epiphytes were washed off the collected samples with sterile seawater (salinity of 32 PSU), followed by acclimation, as described below.

All coral colonies were initially acclimated in $600 \mathrm{~L}$ holding tank for a week in flowing seawater pumped directly from the seawater stock, prepared from natural seawater filtered with Nomex Filter Bag, and treated with 50 ppm chlorine $(50 \mathrm{mg}$ chlorine $\mathrm{L}^{-1}$ ). Water flow within the tank was generated with recirculating pumps (WP-300M, SOBO, China and AT-107, atman, China). Temperature, salinity, and $\mathrm{pH}$ were controlled at levels recorded at the sampling site $\left(29^{\circ} \mathrm{C}, 32 \mathrm{PSU}\right.$, and $\mathrm{pH}$ 8.2). Temperature was regulated using a Heater chiller (CS160CIRV1, atman, China). Irradiance of $150 \mu \mathrm{mol}$ photons $\mathrm{m}^{-2} \mathrm{~s}^{-1}$ (measured with Light Sensor Logger, LI-1500, LICOR, United States) was provided by COB light (TS-A600, Aquarium lamp, China), with 12/12 of light/dark cycle. This irradiance level was non-photoinhibitory (pre-determined in the pilot study) and corresponds to average daily irradiance at the respective sampling periods $(155.83 \pm 8.81 \mu \mathrm{mol}$ photons $\mathrm{m}^{-2} \mathrm{~s}^{-1}$ in May and $156.20 \pm 7.31 \mu \mathrm{mol}$ photons $\mathrm{m}^{-2}$ $\mathrm{s}^{-1}$ in June, Supplementary Table 1). After 1 week, coral colonies were cut into nubbins of $3-5 \mathrm{~cm}$ and distributed into experimental tanks (36 pieces/species/tank, $60 \mathrm{~L} / \mathrm{tank}$ ). The setting of the experiment tank condition was similar to the holding tank, except for the models of temperature chillers (JMC-02, JBA, China) and water pumps (AP-1200, SONIC, China). The coral nubbins were allowed to acclimate for an additional week. One-fourth of the seawater volume was renewed at the end of the week and all physical and chemical parameters were monitored every 2-3 days throughout the acclimation period.

Three plastic boxes containing sods of each seagrass species (six shoots of $T$. hemprichii or approximately 30 leaf pairs of $H$. ovalis in each box) and sediment were combined into an aquarium (40 L, six boxes in total in each aquarium). All aquaria were filled with sterile seawater (salinity of $32 \mathrm{PSU}, \mathrm{pH}$ 8.2 ). Seawater in the aquaria was regularly mixed and filtered using a submersible pump coupled with a microfiber filter (Atman HF-0600, China). Non-photoinhibitory irradiance (predetermined in the pilot study) was provided by aquarium LEDs (A601, Chihiros, China) set at approximately $200 \mu \mathrm{mol}$ photons $\mathrm{m}^{-2} \mathrm{~s}^{-1}$ and 12/12 light/dark cycle. This level corresponds to average daily irradiance at the respective sampling period $\left(199.80 \pm 43.59 \mu \mathrm{mol}\right.$ photons $\mathrm{m}^{-2} \mathrm{~s}^{-1}$, Supplementary Table 1) and is comparable to minimal saturating irradiances $\left[E_{\mathrm{k}}\right]$, pre-determined in situ from the RLCs $(218.39 \pm 19.72 \mu \mathrm{mol}$ photons $\mathrm{m}^{-2} \mathrm{~s}^{-1}$ in T. hemprichii and $225.09 \pm 19.79 \mu \mathrm{mol}$ photons $\mathrm{m}^{-2} \mathrm{~s}^{-1}$ in $H$. ovalis, Diving-PAM, Walz, Effeltrich, Germany). A constant temperature at $30^{\circ} \mathrm{C}$ throughout the acclimation period of the aquaria was maintained using submersible heating rods (EHEIM 3617, EHEIM, Germany). The acclimation period lasted 5 days.

Approximately $20 \mathrm{~g}$ of each macroalgal species were placed in each glass container and anchored to the bottom of the containers with plastic mesh. Other settings followed the seagrass setups.

\section{Experimental Design}

As this study aims to evaluate vulnerability to warming in shallow-water marine organisms, we focused on their stress responses to an increase in temperature within a range recorded in their natural settings encompassing the future warming scenarios. The testing temperatures were chosen based on past SST $\left(27.45 \pm 0.02^{\circ} \mathrm{C}\right.$ to $32.00 \pm 0.02^{\circ} \mathrm{C}$, Figure 1B), records of temperature profiles of the sampling sites $\left(28.84-30.25^{\circ} \mathrm{C}\right.$ in shallow water coral reefs and $26.96-36.70^{\circ} \mathrm{C}$ in tidal flat areas at the respective sampling periods, Supplementary Table 1), our previous investigations (Rasmusson et al., 2020, 2021; unpublished data) and other studies from the tropical shallow waters (Sutthacheep et al., 2013a; Collier and Waycott, 2014; Pedersen et al., 2016; George et al., 2018; Kong et al., 2019). Extreme temperatures, exceeding $40^{\circ} \mathrm{C}$, have been reported in tropical seagrass meadows (Collier and Waycott, 2014; Pedersen et al., 2016; George et al., 2018) whereas the highest temperature reported in shallow water coral reefs in Thailand was $32.7^{\circ} \mathrm{C}$ (Sutthacheep et al., 2013a). As corals are exposed to smaller thermal variations in situ compared to seagrasses and macroalgae (Supplementary Table 1), narrower range of temperature with smaller increment was thus adopted for coral experimental design.

The experiment was continued in the same setups for acclimatization and divided into two phases: 5 days of stress and 5 days of recovery. The stress period consisted of four treatments (1) $27^{\circ} \mathrm{C}$ (2) $29.5^{\circ} \mathrm{C}$ (2) $32^{\circ} \mathrm{C}$, and (4) $34.5^{\circ} \mathrm{C}$ for corals and (1) $27^{\circ} \mathrm{C}(2) 32^{\circ} \mathrm{C}(2) 37^{\circ} \mathrm{C}$, and (4) $42^{\circ} \mathrm{C}$ for seagrasses and macroalgae. During the stress period, the maximum quantum yield of photosystem II $\left(F_{\mathrm{v}} / F_{\mathrm{m}}\right)$ and photosystem II potential 


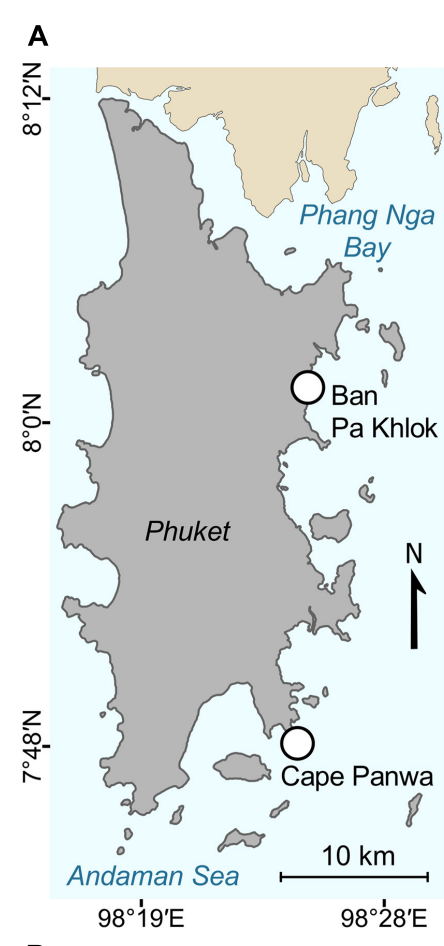

\section{C}

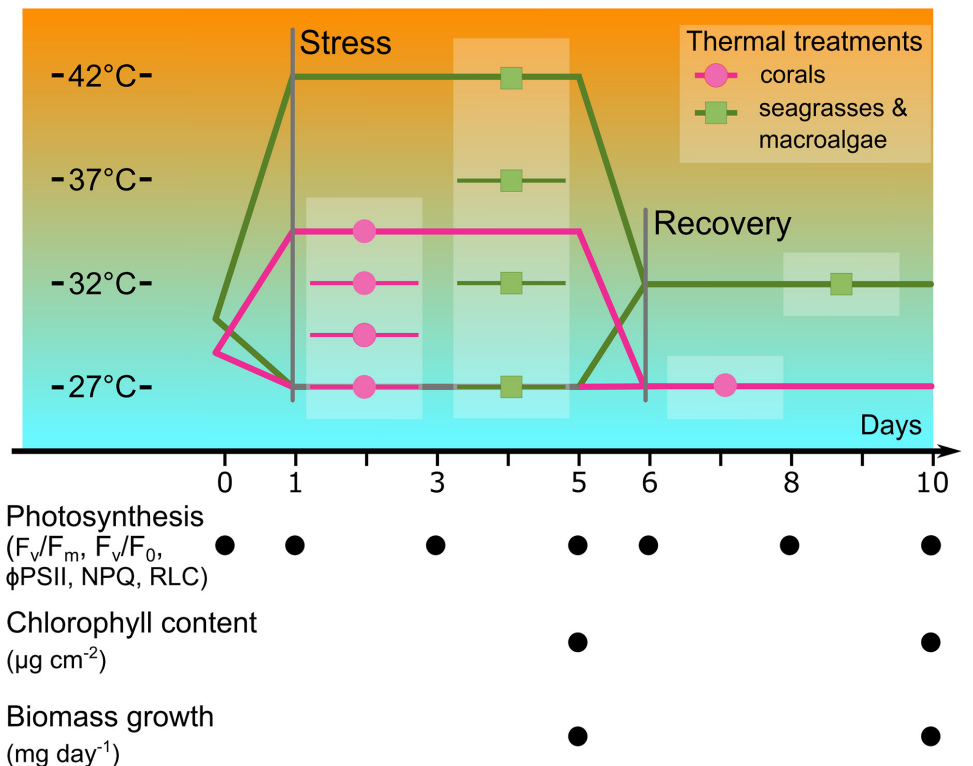

Integrated Biomarker Response (IBR) index

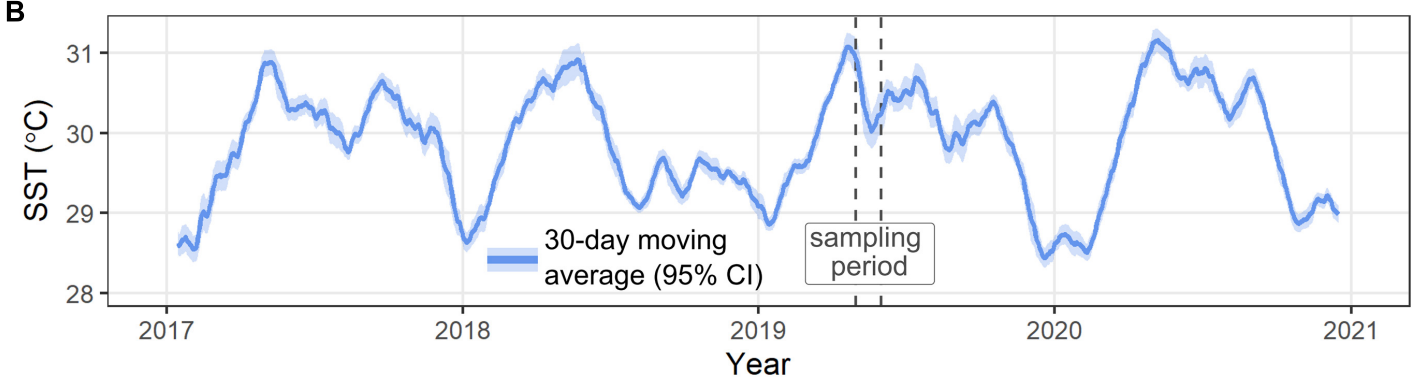

FIGURE 1 | (A) Locations of the sampling sites, (B) average sea surface temperature (SST) in coastal water of Phuket recorded from 2017 to 2020 and (C) experimental design, timeline and investigated parameters. Sea surface temperatures were retrieved from GHRSST Level 4 MUR Global Foundation Sea Surface Temperature Analysis (v4.1) (https://podaac.jpl.nasa.gov/dataset/MUR-JPL-L4-149GLOB-v4.1 accessed on July 01, 2021).

activity $\left(F_{\mathrm{v}} / F_{0}\right)$ were assessed on days 0,3 , and 5 before the light was turned on, whereas the effective quantum yield ( $\phi$ PSII) and RLCs were assessed in the middle of the photoperiod on the same day. At the end of the stress period, the biological materials were randomly collected from all treatments for further analysis of photosynthetic pigments, while zooxanthellae density was assessed in the coral samples. Growth rates and biomass loss rates (when applicable) were determined at the end of the stress period (as detailed below). A recovery period was initiated by adjusting the temperature of all aquaria to $27^{\circ} \mathrm{C}$ for corals and $32^{\circ} \mathrm{C}$ for seagrasses and macroalgae (pre-determined in the preliminary study as the optimal temperature). All species were subjected to the new temperature regime for an additional 5 days and the same measurements were done as described for the stress period. The seawater was renewed before starting the stress period and before starting the recovery period. Salinity was measured every day using a refractometer and, when necessary, adjusted to 32 PSU by adding distilled water. The experimental design and timeline for the measurements are summarized in Figure 1C.

\section{Measurement Protocols Chlorophyll Fluorescence}

The parameters associated with the integrity of photosystem II; $F_{\mathrm{v}} / F_{\mathrm{m}}$, and $F_{\mathrm{v}} / F_{0}$ were assessed before the light was turned on using a Pulse Amplitude Modulated Fluorometer (DivingPAM, Walz, Effeltrich, Germany). The two parameters $\underline{F}_{\mathrm{v}} / F_{\mathrm{m}}$ and $F_{\mathrm{v}} / F_{0}$ were calculated from $\left(F_{\mathrm{m}}-F_{0}\right) / F_{\mathrm{m}}$ and $\left(F_{\mathrm{m}}-F_{0}\right) / F_{0}$, respectively; where $F_{0}$ represents minimum fluorescence of dark-adapted biological materials and $F_{\mathrm{m}}$ represents maximum fluorescence after saturating pulse is applied.

The $\phi$ PSII and RLC were constructed in the middle of the photoperiod (Diving-PAM, Walz, Effeltrich, Germany). Measurements in the light were assisted by distant leaf clip (Distance Clip 60 2010-A, Walz, Effeltrich, Germany), which 
kept the angle and distance between the Diving-PAM optical fiber and coral surface and the algal thalli and plant leaves fixed. The $\phi$ PSII was calculated from $\left(F_{\mathrm{m}}^{\prime}-F\right) / F_{\mathrm{m}}^{\prime}$; where $F$ represents minimum fluorescence of light-adapted biological materials and $F_{\mathrm{m}}^{\prime}$ represents maximum fluorescence after saturating pulse is applied.

For RLCs, a series of photosynthetic active radiation (PAR) was provided by the optical fiber ranging from 45 to $617 \mu \mathrm{mol}$ photons $\mathrm{m}^{-2} \mathrm{~s}^{-1}$ and with $20 \mathrm{~s}$ increment step. The $\phi$ PSII was determined after each PAR step. The electron transport rates (ETR) were subsequently calculated by multiplying $\phi$ PSII by PAR and 0.5 (based on the assumption that absorbed photons are equally divided between photosystems I and photosystem II) and by the preset absorption factor $(\mathrm{AF}=0.84)$. The ETRs, as the functions of PAR, were plotted and fitted using the equation of Platt et al. (1980) from which the photosynthetic parameters, including asymptotic maximum levels of ETR $\left(\mathrm{ETR}_{\max }\right)$, the initial slope of the light response curve $(\alpha)$, and minimum saturating irradiance $\left(E_{\mathrm{k}}\right)$, were estimated.

Diving-PAM settings for measurements taken in corals were as follows: intensity of measuring light 2 (MEAS-INT), electronic signal gain 3 (GAIN), saturation pulse intensity 8 (SAT-INT), width of saturating light pulse $0.6 \mathrm{~s}$ (SATWIDTH). Measurements done in seagrasses and macroalgae followed the settings used in corals except for GAIN which was lowered to 2. The photosynthetic parameters were measured in three replicate tanks with three sub-replicates. As it has been shown that photosynthetic characteristics vary significantly depending on age and position of the photosynthetic tissues (e.g., along the thallus or leaf blade) (Colombo-Pallota et al., 2006; Schubert et al., 2015), the same areas of the same individuals were used for the determination of chlorophyll fluorescence parameters throughout the experiment. The coral surface areas were randomly selected. The photosynthetic parameters of $H$. ovalis were measured in the middle area of the leaf, whereas those of T. hemprichii were measured at the middle section of the second youngest leaf. The photosynthetic parameters of macroalgae were measured at the middle section of the algal thallus.

\section{Determination of Zooxanthellae Density}

Coral tissue was removed from the skeleton using an airbrush and the slurry was centrifuged for $10 \mathrm{~min}$ at $1,500 \mathrm{rpm}$ and $4^{\circ} \mathrm{C}$ to obtain a well-mixed sample. A hemocytometer was used to count the zooxanthellae cells within a $1 \mathrm{ml}$ aliquot under a light microscope $(40 \times)$. All coral skeletons were completely bleached in $10 \%$ Sodium Hypochlorite and washed several times. The surface area was determined using the paraffin wax technique on bleached skeleton and quantified using a standard curve (Hill and Ralph, 2007; Veal et al., 2010). The zooxanthellae density was calculated as the total number of cells per unit coral surface area.

\section{Determination of Photosynthetic Pigments}

Total chlorophylls of corals were determined in the remaining solution after the cell number was determined, as described above. The slurry was centrifuged for $5 \mathrm{~min}$ at 5,000 rpm and $4^{\circ} \mathrm{C}$ and the supernatant was discarded. The algal pellets were resuspended in $90 \%$ acetone and stored in darkness for $24 \mathrm{~h}$ at $4^{\circ} \mathrm{C}$.
The centrifugation was subsequently repeated, and the obtained supernatant was collected. Total chlorophylls (chlorophyll $a+c_{2}$ ) were determined using the standard spectrophotometric method of Ritchie (2006), with absorbance measured at 630, 664, and $750 \mathrm{~nm}$. Total chlorophylls were normalized against coral surface area pre-determined using the paraffin wax technique, as mentioned above.

Seagrass and macroalgal tissues were ground using a mortar and pestle in $80 \%$ acetone. The homogenate was kept in darkness for $72 \mathrm{~h}$ and then centrifuged at $1,000 \times g$ for $10 \mathrm{~min}$ before the absorbance was measured at 664, 647, and $470 \mathrm{~nm}$ (Metertech SP-8001 UV/Visible Spectrophotometer, Taiwan). Before the extraction, photographs of all the samples were promptly taken and the wet weight was recorded. The surface areas of the algal thallus and seagrass leafs were estimated using the ImageJ program ${ }^{1}$. Total chlorophylls (chlorophyll $a+b$ ) were calculated according to the method described by Porra (2002) and normalized against the surface area.

\section{Determination of Growth-Related Attributes}

As the three groups of organisms used for this study exhibit varying growth forms, different approaches were adopted to measure their growth-related attributes. All measurements were done in a non-destructive manner, such that the same individuals were used for growth assessment at the end of the stress period as well as at the end of the recovery period. Growth rates of corals and macroalgae were expressed as a net increase in biomass (mg) per day, whereas growth-related attributes of seagrasses were expressed as an increase in biomass per day and senescent biomass per day.

The buoyant weight technique was used to measure the coral skeleton growth rate (Jokiel and Guinther, 1978). The same coral nubbin was weighted at the start, end of stress period, and at end of the recovery period using a 4-digit precision balance (Ohaus, United States). In each measurement, the seawater temperature and salinity were recorded for the calculation of seawater density, and glass reference was weighed in both sea water and air (Davies, 1989). The skeleton bulk densities of $P$. lutea and $P$. acuta were calculated according to the methods described by Ng et al. (2019), respectively. Coral growth rates were expressed as net increases in biomass (mg) per day. Negative values were shown when there was a net loss in the biomass weight.

At the beginning of the experiment, at the end of the stress period, and at the end of the recovery period, photographs of $H$. ovalis in each box were taken and the number of living and dead leaves were later counted. Both growth rates and senescence rates were recorded as an increase in the number of viable leaves and an increase in the number of dead leaves, respectively. At the end of the experiment, leaf fresh weight was measured to give an estimate of the weight per leaf $(n=50)$. This value was used to convert the growth rates and senescence rates into an increase in biomass (mg) and senescent biomass (mg) per day, respectively. For T. hemprichii, leaf area gained was assessed using the leaf marking method (Short and Duarte, 2001). In brief, all of the leaves in each shoot were punched

\footnotetext{
${ }^{1}$ http://rsb.info.nih.gov/ij/
} 
using hypodermic needles at the meristematic tissue at the base of the shoot. The first mark provided an initial reference level and new growth increments were measured at the end of the stress period. The same steps were applied for the recovery period. The leaf growth rate expressed as $\mathrm{mm}^{2}$ day ${ }^{-1}$ was subsequently obtained. Similarly, weight per area of the green leaves of T. hemprichii was determined $(n=50)$ and this constant was used to estimate an increase in biomass ( $\mathrm{mg}$ ) per day. The biomass loss of T. hemprichii was determined from both the dead areas of undetached leaves and the weight of shed leaves during the stress and recovery period. The dead areas of undetached leaves were converted to biomass using the same constant for the viable leaf. Senescence rates were expressed as biomass (mg) loss per day.

At the beginning of the experiment, at the end of the stress period, and at the end of the recovery period, the wet weight of $P$. boryana and $U$. intestinalis was recorded. The algal thalli were carefully dried using paper towels before weighing with a 4digit precision balance (Ohaus, United States). Their growth rates were expressed as net increase in biomass ( $\mathrm{mg}$ ) per day. Negative values were shown when there was a net loss in the algal biomass.

\section{Integrated Biomarker Response}

Integrated Biomarker Response (IBR) approach was used to quantify the overall effects of temperature on each species through an integrated response of $F_{\mathrm{V}} / F_{\mathrm{m}}$, chlorophyll content, and growth rate. The biomarkers used in this analysis were chosen as the representatives for the responses at physiological, biochemical, and whole-organism levels. The IBR indices were analyzed according to the method of Beliaeff and Burgeot (2002) as described by Madeira et al. (2018). For each biomarker, the general mean $(\mathrm{m})$ and standard deviation $(\mathrm{s})$ of all treatments combined were calculated and standardized $(Y)$ as $Y=(X-m) / \mathrm{s}$; where $X$ is the mean value for the biomarker at a given treatment. $Z$ was then calculated as $Z=-Y$ or $Z=Y$ in the case of biological effects corresponding to inhibition or activation, respectively. The score (S) was computed as $S=Z+\mid$ Min|; where $S \geq 0$ and | Min| is the absolute value for the minimum of all $Y$ calculated in a given biomarker. The score results $(S)$ were presented as star plots and used to calculate the IBR as:

$$
\begin{gathered}
\text { IBR }=\sum_{i=1}^{n} A_{i} \\
A_{i}=\frac{S_{i}}{2} \sin \beta\left(S_{i} \cos \beta+S_{i+1} \sin \beta\right)
\end{gathered}
$$

Where

$$
\beta=\tan ^{-1}\left(\frac{S_{i+1} \sin \alpha}{S_{i}-S_{i+1} \cos \alpha}\right)
$$

Where $\mathrm{Si}$ and $\mathrm{S}_{\mathrm{i}+1}$ are two consecutive clockwise scores (radius coordinates) of a given star plot; $A_{\mathrm{i}}$ corresponds to the area connecting two scores; $n$ is the number of biomarkers used for the calculations; and $\alpha=2 \pi / n$ (Beliaeff and Burgeot, 2002; Madeira et al., 2018).

\section{Statistical Analysis}

All statistical analyses were performed separately for each group of organisms (corals, macroalgae, or seagrasses). The photosynthetic parameters derived by PAM measurements $\left(F_{\mathrm{v}} / F_{\mathrm{m}}, F_{\mathrm{v}} / F_{0}, \phi\right.$ PSII, ETR $\max , E_{\mathrm{k}}$, and $\left.\alpha\right)$ and growth rates were analyzed by repeated-measures analysis of variance (ANOVA) using time of measurements as the within-group factor and thermal treatments and species as the categorical factors. The statistical significance of differences in total chlorophyll content and coral zooxanthellae density was determined by factorial ANOVA using temperatures, species, and treatment period (stress and recovery) as categorical factors. Fisher's least significant difference (LSD) test was used for post hoc comparisons. Cochran's test was used to test the assumption of homogeneity of variances before performing the ANOVAs. All analyses were performed with Statistica Academic Version 13.0.

\section{RESULTS}

Both temperature and time of exposure were found to affect the overall performance of all species, which manifested as a reduction in photosynthesis, pigment content, and growth rates (for complete ANOVA statistical results, see Supplementary Table 2). However, the sensitivity differed among species. The highest temperature applied in the present study $\left(34.5^{\circ} \mathrm{C}\right.$ for corals and $42^{\circ} \mathrm{C}$ for seagrasses and macroalgae) had lethal effects on all the tested species.

\section{Photosynthetic Responses Maximum Quantum Yield of PSII $\left(F_{\mathrm{v}} / F_{\mathrm{m}}\right)$, PSII Potential Activity $\left(F_{\mathrm{v}} / F_{0}\right)$ and Effective Quantum Yield (Psi PSII)}

Repeated-measures ANOVA (repeated ANOVA) showed significant effects of temperature $(p<0.001)$, time of measurement $(p<0.001)$, and interaction of these factors $(p<0.001)$ on the maximum quantum yield of PSII $\left(F_{\mathrm{v}} / F_{\mathrm{m}}\right)$ of corals. At $27^{\circ} \mathrm{C}$ and $29.5^{\circ} \mathrm{C}, F_{v} / F_{m}$ showed slight variations among days, but these variations were not statistically significant. In contrast, exposure to 32 and $34.5^{\circ} \mathrm{C}$ resulted in a significant decrease in $F_{\mathrm{v}} / F_{\mathrm{m}}$ (Figure $2 \mathrm{~A}$ ), with a more rapid decline and lethal effect at $34.5^{\circ} \mathrm{C}$ (Fisher's LSD test). Both $P$. acuta and $P$. lutea pre-exposed to $32^{\circ} \mathrm{C}$ fully recovered on day 3 of the recovery period. There were significant effects of temperature (repeated ANOVA, $p<0.001$ ), species (repeated ANOVA, $p<0.001$ ), time of measurement (repeated ANOVA, $p<0.001$ ), and interaction of these factors (repeated ANOVA, $p<0.001$ ) on PSII potential activity $\left(F_{\mathrm{V}} / F_{0}\right)$ of corals. Although $F_{\mathrm{v}} / F_{0}$ followed a similar trend as observed in $F_{\mathrm{v}} / F_{\mathrm{m}}$, it exhibited higher variability and higher sensitivity (Figure $2 \mathbf{B}$ ). In other words, a significant decrease in $F_{\mathrm{v}} / F_{0}$ than $F_{\mathrm{v}} / F_{\mathrm{m}}$ was detected earlier and at a lower temperature. Full recovery was observed in the samples pre-exposed to $29.5^{\circ} \mathrm{C}$, whereas partial recovery was observed in the samples exposed to $32^{\circ} \mathrm{C}$.

Repeated ANOVA revealed significant effects of temperature $(p<0.001)$, species $(p<0.001)$, time of measurement $(p<0.001)$, and interaction of these factors $(p<0.05)$ on the 


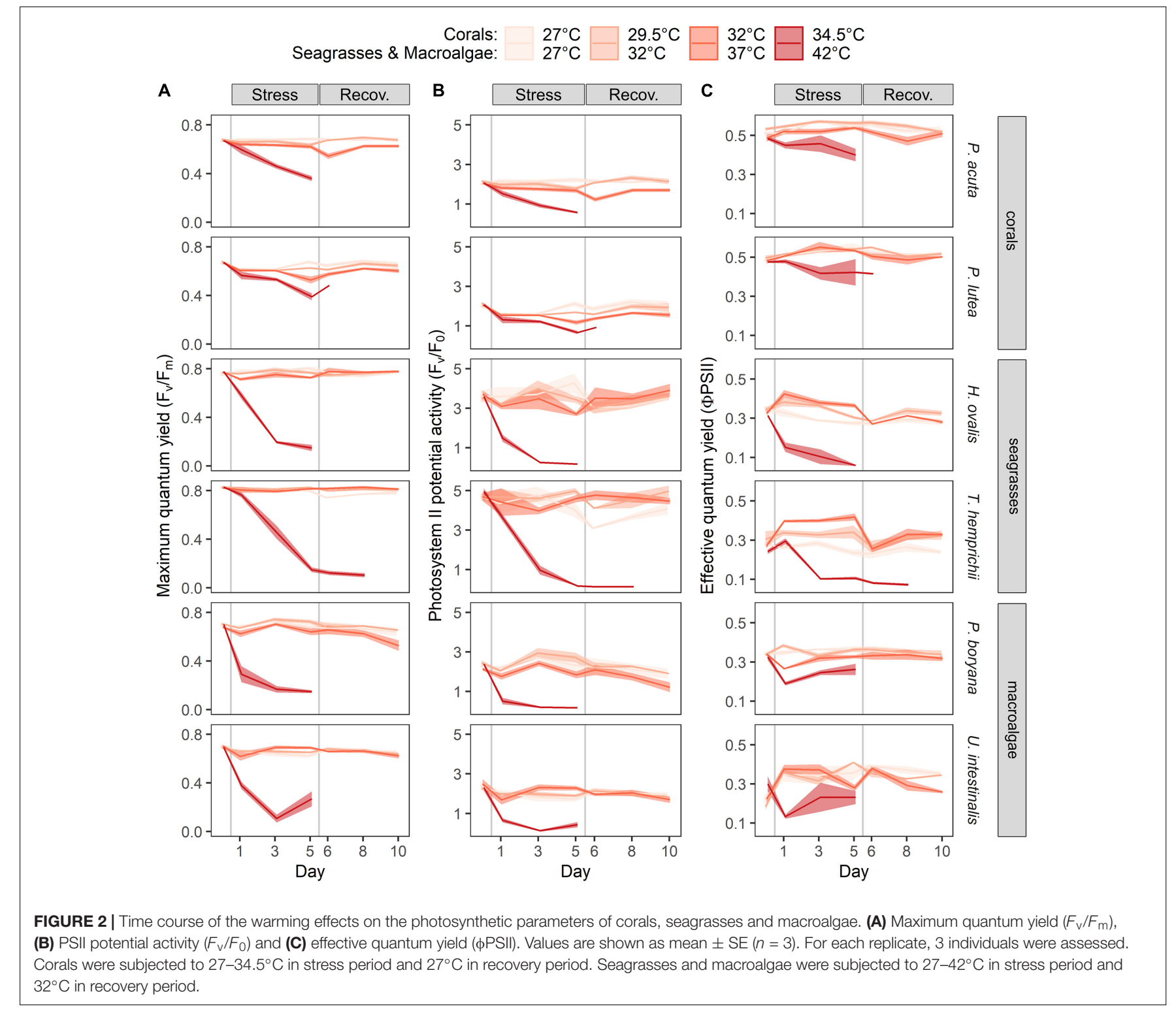

$F_{\mathrm{V}} / F_{\mathrm{m}}$ and $F_{\mathrm{v}} / F_{0}$ of seagrasses (Figures 2A,B). At 27, 32, and $37^{\circ} \mathrm{C}, F_{\mathrm{v}} / F_{\mathrm{m}}$ showed slight variations among the days; however, these variations were not statistically significant. In contrast, exposure to $42^{\circ} \mathrm{C}$ resulted in a significant decrease in $F_{\mathrm{v}} / F_{\mathrm{m}}$ (Figure 2A). $\mathrm{H}$. ovalis exposed to $42^{\circ} \mathrm{C}$ showed a decrease in $F_{\mathrm{v}} / F_{\mathrm{m}}$ compared to the initial values on day 1 after treatment (Fisher's LSD test), followed by a drastic decline in $F_{\mathrm{v}} / F_{\mathrm{m}}$ until it was not detectable after day 5. T. hemprichii appeared to be more resistant to thermal stress (following exposure of the plants to $42^{\circ} \mathrm{C}$ ), showing a decrease in $F_{\mathrm{v}} / F_{\mathrm{m}}$ compared to the initial values on day 3 after treatment (Fisher's LSD test), followed by a drastic decline until it was not detectable after day 3 of the recovery period. The $F_{\mathrm{v}} / F_{0}$ in seagrasses also showed a higher sensitivity than $F_{\mathrm{v}} / F_{\mathrm{m}}$, since a significant decrease was observed at both 37 and $42^{\circ} \mathrm{C}$ (Figure 2B, Fisher's LSD test). While mortality was seen in plants exposed to $42^{\circ} \mathrm{C}$, complete recovery was detected in plants pre-exposed to $37^{\circ} \mathrm{C}$. In addition, T. hemprichii also showed a reduction in $F_{\mathrm{v}} / F_{0}$ when exposed to $27^{\circ} \mathrm{C}$; however, full recovery was achieved at the end of the recovery period.

There were significant effects of temperature (repeated ANOVA, $p<0.001)$, time of measurement $(p<0.001)$, and interaction of these factors $(p<0.05)$ on the $F_{\mathrm{v}} / F_{\mathrm{m}}$ and $F_{\mathrm{v}} / F_{0}$ of macroalgae (Figure 2A). At 27, 32, and $37^{\circ} \mathrm{C}, F_{\mathrm{v}} / F_{\mathrm{m}}$ showed slight variations among the days; however, these variations were not statistically significant, with an exception in $P$. boryana exposed to $37^{\circ} \mathrm{C}$, where a marginal difference from the initial value was detected on day 5 of the recovery period. Both macroalgae exposed to $42^{\circ} \mathrm{C}$ displayed a drastic decline in $F_{\mathrm{v}} / F_{\mathrm{m}}$ compared to the initial values on day 1 after treatment, followed by a steady decline, which became undetectable after day 5 . Similar trend was observed in $F_{\mathrm{v}} / F_{0}$ (Figure 2B). 


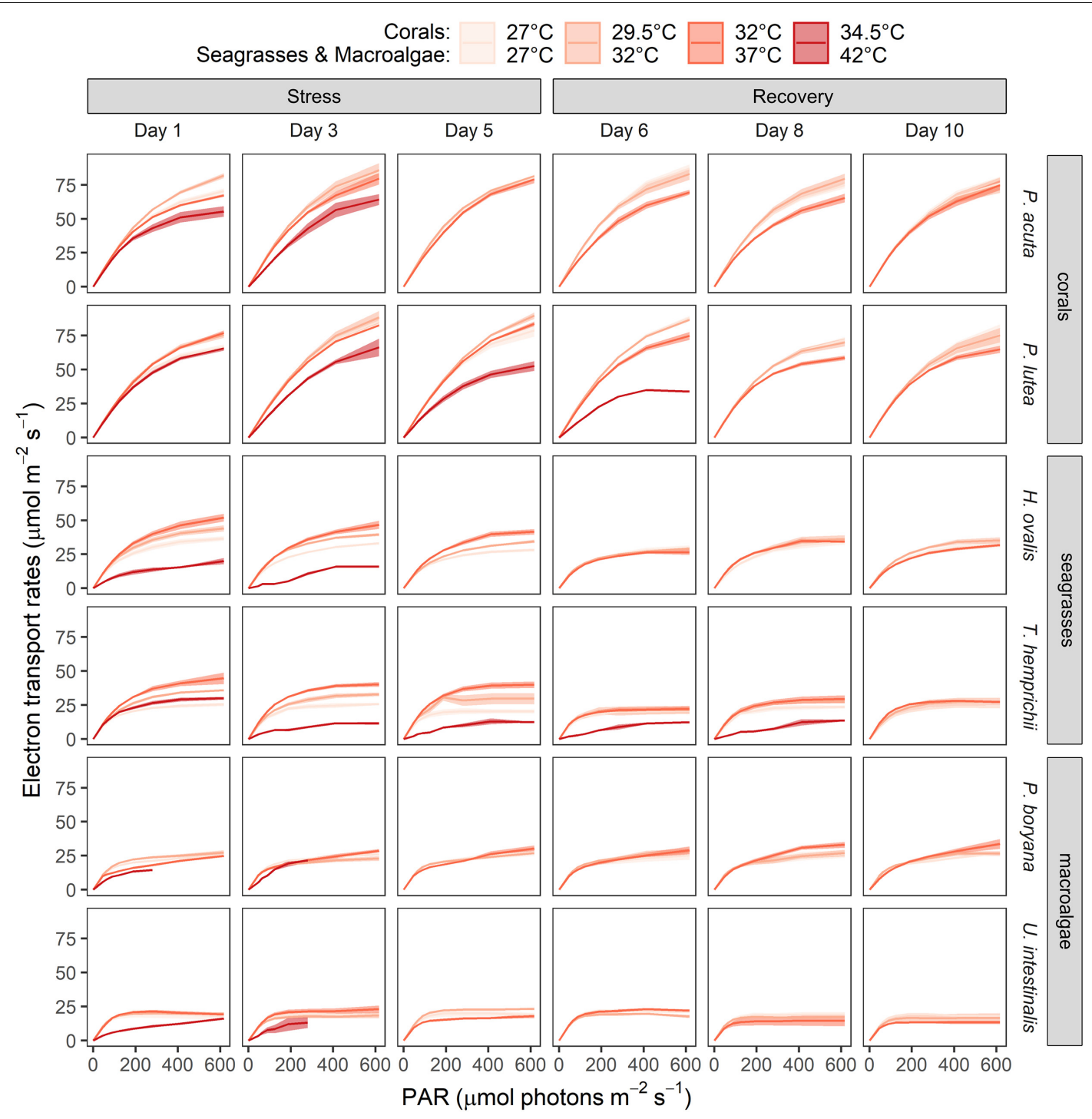

FIGURE 3 | Time course of the warming effects on the rapid light response curves of corals, seagrasses and macroalgae. Values are shown as mean \pm SE $(n=3)$. For each replicate, 3 individuals were assessed. Corals were subjected to $27-34.5^{\circ} \mathrm{C}$ in stress period and $27^{\circ} \mathrm{C}$ in recovery period. Seagrasses and macroalgae were subjected to $27-42^{\circ} \mathrm{C}$ in stress period and $32^{\circ} \mathrm{C}$ in recovery period.

The response pattern of the effective quantum yield ( $\phi$ PSII) in all species followed that of $F_{\mathrm{v}} / F_{\mathrm{m}}$ except for $T$. hemprichii of which an increase in $\phi$ PSII was observed as temperature increased from 27 to $37^{\circ} \mathrm{C}$ (Figure 2C, Fisher's LSD test).

\section{Rapid Light Curves}

Increasing temperatures also exerted negative effects on light use efficiency, which was measured as rapid light curve-derived parameters (Figure 3, data are shown in Supplementary Table 3). The highest temperatures applied in the present study $\left(34.5^{\circ} \mathrm{C}\right.$ for corals and $42^{\circ} \mathrm{C}$ for seagrasses and macroalgae) had lethal effects on all the tested species. Toward the end of the stress period of these temperatures, the RLCs of some species did not show any functional response fitted for the equations used and were therefore omitted from the dataset.
All parameters, including the asymptotic maximum levels of ETR $\left(\mathrm{ETR}_{\max }\right)$, initial slope of the light response curve $(\alpha)$, and minimum saturating irradiance $\left(E_{\mathrm{k}}\right)$ of all organisms varied according to temperature, time of exposure, and among species (Supplementary Table 3). As ETR max $_{\text {ax }}$ exhibited the most obvious temperature-dependent response among the three parameters, it was selected as a proxy to describe the effects of heat stress on the photosynthetic capacity of the marine organisms tested in the present study (Table 1).

In corals, $\mathrm{ETR}_{\max }$ were affected by temperature (repeated ANOVA, $p<0.001)$, duration of exposure $(p<0.001)$, and interactions of these factors $(p<0.05)$. While temporal variations were detected (Fisher's LSD test), the comparison of the values measured on the same day revealed a lower $\mathrm{ETR}_{\max }$ at 32 and $34.5^{\circ} \mathrm{C}$ (Fisher's LSD test, Table 1). At the 
TABLE 1 | The maximum electron transport rates $\left(\mu \mathrm{mol} \mathrm{m}^{-2} \mathrm{~s}^{-1}\right.$, ETR $\max$ ) derived from the rapid light curves (mean $\pm \mathrm{SE}, n=3$ ).

\begin{tabular}{|c|c|c|c|c|c|c|c|}
\hline \multirow[t]{2}{*}{ Species/treatments } & \multirow[t]{2}{*}{ Day 0} & \multicolumn{3}{|c|}{ Stress period } & \multicolumn{3}{|c|}{ Recovery period } \\
\hline & & Day 1 & Day 3 & Day 5 & Day 6 & Day 8 & Day 10 \\
\hline \multicolumn{8}{|l|}{ Pocillopora acuta } \\
\hline - $27^{\circ} \mathrm{C}$ & $64.24 \pm 3.68$ & $70.38 \pm 1.84$ & $84.37 \pm 1.51$ & $80.58 \pm 1.51$ & $87.05 \pm 2.84$ & $74.83 \pm 2.39$ & $76.02 \pm 4.90$ \\
\hline - $29.5^{\circ} \mathrm{C}$ & $63.43 \pm 2.677$ & $81.83 \pm 1.83$ & $85.68 \pm 5.16$ & $81.47 \pm 0.85$ & $82.97 \pm 4.27$ & $79.45 \pm 3.78$ & $74.79 \pm 5.60$ \\
\hline - $32^{\circ} \mathrm{C}$ & $62.74 \pm 3.94$ & $67.25 \pm 1.04$ & $79.59 \pm 4.35$ & $74.23 \pm 0.90$ & $69.51 \pm 1.78$ & $65.30 \pm 3.24$ & $74.78 \pm 3.56$ \\
\hline - $34.5^{\circ} \mathrm{C}$ & $76.34 \pm 0.50$ & $55.42 \pm 3.86$ & $65.53 \pm 2.61$ & - & - & - & - \\
\hline \multicolumn{8}{|l|}{ Porites lutea } \\
\hline - $27^{\circ} \mathrm{C}$ & $55.32 \pm 2.196$ & $66.33 \pm 2.04$ & $85.50 \pm 3.95$ & $78.81 \pm 4.56$ & $88.11 \pm 1.40$ & $71.86 \pm 2.05$ & $75.64 \pm 7.58$ \\
\hline - $29.5^{\circ} \mathrm{C}$ & $62.18 \pm 2.20$ & $75.49 \pm 2.18$ & $88.42 \pm 4.63$ & $89.68 \pm 2.33$ & $86.76 \pm 1.06$ & $70.02 \pm 2.89$ & $75.29 \pm 5.34$ \\
\hline - $32^{\circ} \mathrm{C}$ & $61.26 \pm 2.21$ & $76.98 \pm 1.81$ & $82.52 \pm 0.50$ & $83.66 \pm 1.67$ & $74.80 \pm 2.91$ & $58.62 \pm 1.73$ & $64.95 \pm 2.69$ \\
\hline - $34.5^{\circ} \mathrm{C}$ & $61.49 \pm 0.66$ & $65.54 \pm 1.60$ & $70.29 \pm 2.93$ & $52.68 \pm 3.60$ & $33.91^{\star}$ & - & - \\
\hline \multicolumn{8}{|l|}{ Halophila ovalis } \\
\hline - $27^{\circ} \mathrm{C}$ & $34.41 \pm 0.95$ & $35.01 \pm 1.96$ & $31.12 \pm 0.79$ & $26.82 \pm 1.09$ & $27.95 \pm 2.09$ & $33.19 \pm 2.38$ & $30.89 \pm 2.28$ \\
\hline - $32^{\circ} \mathrm{C}$ & $31.10 \pm 1.13$ & $42.38 \pm 2.14$ & $37.87 \pm 1.00$ & $32.72 \pm 0.91$ & $2728 \pm 0.72$ & $35.15 \pm 2.94$ & $34.36 \pm 1.94$ \\
\hline - $37^{\circ} \mathrm{C}$ & $36.57 \pm 1.67$ & $50.39 \pm 3.04$ & $45.05 \pm 2.72$ & $40.86 \pm 2.18$ & $25.91 \pm 1.32$ & $33.83 \pm 1.11$ & $30.18 \pm 0.98$ \\
\hline - $42^{\circ} \mathrm{C}$ & $40.21 \pm 2.43$ & $19.17 \pm 1.62$ & $12.07 \pm 4.50$ & - & - & - & - \\
\hline \multicolumn{8}{|l|}{ Thalassia hemprichii } \\
\hline - $27^{\circ} \mathrm{C}$ & $23.66 \pm 1.21$ & $24.13 \pm 1.12$ & $24.87 \pm 1.30$ & $20.35 \pm 1.81$ & $20.26 \pm 1.99$ & $23.33 \pm 1.46$ & $23.27 \pm 0.53$ \\
\hline - $32^{\circ} \mathrm{C}$ & $21.47 \pm 1.11$ & $34.66 \pm 0.76$ & $31.61 \pm 1.68$ & $29.10 \pm 4.19$ & $20.82 \pm 3.12$ & $27.24 \pm 1.46$ & $27.05 \pm 2.98$ \\
\hline - $37^{\circ} \mathrm{C}$ & $24.46 \pm 0.62$ & $43.32 \pm 4.03$ & $39.22 \pm 1.65$ & $39.48 \pm 2.33$ & $21.42 \pm 1.81$ & $28.86 \pm 2.71$ & $27.50 \pm 0.85$ \\
\hline - $42^{\circ} \mathrm{C}$ & $26.80 \pm 3.64$ & $28.68 \pm 1.45$ & $11.60 \pm 0.60$ & $13.38 \pm 1.01$ & $13.01 \pm 3.07$ & $13.01 \pm 3.60$ & - \\
\hline \multicolumn{8}{|l|}{ Padina boryana } \\
\hline$\cdot 27^{\circ} \mathrm{C}$ & $22.74 \pm 1.48$ & $25.14 \pm 0.36$ & $26.18 \pm 0.31$ & $28.03 \pm 2.88$ & $25.20 \pm 3.08$ & $26.28 \pm 2.78$ & $27.03 \pm 0.82$ \\
\hline - $32^{\circ} \mathrm{C}$ & $23.69 \pm 1.24$ & $27.26 \pm 1.79$ & $23.02 \pm 1.72$ & $27.02 \pm 0.57$ & $28.75 \pm 1.57$ & $26.94 \pm 2.51$ & $27.02 \pm 1.38$ \\
\hline - $37^{\circ} \mathrm{C}$ & $22.82 \pm 0.83$ & $25.23 \pm 0.86$ & $28.69 \pm 1.24$ & $30.40 \pm 2.26$ & $28.97 \pm 2.81$ & $33.48 \pm 1.92$ & $33.99 \pm 3.46$ \\
\hline - $42^{\circ} \mathrm{C}$ & $22.71 \pm 1.79$ & $24.80 \pm 0.29$ & $21.63 \pm 1.36$ & - & - & - & - \\
\hline \multicolumn{8}{|l|}{ Ulva intestinalis } \\
\hline$\cdot 27^{\circ} \mathrm{C}$ & $13.13 \pm 1.07$ & $20.22 \pm 2.92$ & $20.49 \pm 2.51$ & $20.54 \pm 2.50$ & $22.83 \pm 1.20$ & $20.26 \pm 2.29$ & $19.72 \pm 1.19$ \\
\hline - $32^{\circ} \mathrm{C}$ & $14.56 \pm 1.38$ & $20.75 \pm 1.10$ & $18.29 \pm 1.18$ & $23.15 \pm 0.84$ & $20.19 \pm 1.24$ & $17.46 \pm 0.54$ & $18.61 \pm 3.53$ \\
\hline - $37^{\circ} \mathrm{C}$ & $13.89 \pm 0.50$ & $21.48 \pm 1.25$ & $22.18 \pm 2.16$ & $18.65 \pm 2.02$ & $20.91 \pm 3.00$ & $15.33 \pm 3.70$ & $13.72 \pm 1.03$ \\
\hline - $42^{\circ} \mathrm{C}$ & $13.85 \pm 2.57$ & $16.24 \pm 0.58$ & $13.16 \pm 4.05$ & - & - & - & - \\
\hline
\end{tabular}

For each replicate, 3 individuals were assessed.

Asterisk $\left(^{*}\right)$ indicates the treatment in which there was only one replicate of fitted rapid light curve $(n=1)$.

end of the recovery period, $P$. acuta pre-exposed to $32^{\circ} \mathrm{C}$ fully recovered, whereas photoinhibition in $P$. lutea pre-exposed to $32^{\circ} \mathrm{C}$ was not alleviated (Fisher's LSD test). In seagrasses, $\mathrm{ETR}_{\max }$ was affected by temperature (repeated ANOVA, $p<0.001$ ), duration of exposure $(p<0.001)$, species $(p<0.001)$, and interactions of these factors $(p<0.05)$. From 27 to $37^{\circ} \mathrm{C}$, ETR $_{\max }$ of $H$. ovalis and T. hemprichii showed an increasing trend with increasing temperature when comparing the values measured on the same day, while exposure to $42^{\circ} \mathrm{C}$ led to a significant decline in $\mathrm{ETR}_{\max }$ (Fisher's LSD test), which is in line with the response of $\phi$ PSII. Nevertheless, plants pre-exposed to $27-37^{\circ} \mathrm{C}$ exhibited a comparable $\mathrm{ETR}_{\max }$ in the recovery period. In macroalgae, the effect of sublethal temperature was less prominent (Figure 3 and Table 1). ETR max $_{\text {ma }}$ was affected by the duration of exposure (repeated ANOVA, $p<0.001)$ and species $(p<0.001)$, but not temperature. Nevertheless, post hoc comparisons (Fisher's LSD test) showed that $U$. intestinalis, at $42^{\circ} \mathrm{C}$, had the lowest $\mathrm{ETR}_{\max }$ on days 1 and 3 of the stress period.

\section{Chlorophyll Content}

Total chlorophylls in both coral species (Figure 4) varied according to temperature (factorial ANOVA, $p<0.05$ ), time of sampling $(p<0.001)$, and interactions between the two factors $(p<0.001)$. At the end of the stress period, total chlorophyll of $P$. acuta exposed to $27,29.5$, and $32^{\circ} \mathrm{C}$ remained similar and was higher than total chlorophyll of individuals exposed to $34.5^{\circ} \mathrm{C}$ (Fisher's LSD test). A further decline in the total chlorophyll after the recovery period was detected in individuals pre-exposed to $34.5^{\circ} \mathrm{C}$ (Fisher's LSD test). On the other hand, chlorophyll content of $P$. lutea decreased after exposure to 32 and $34.5^{\circ} \mathrm{C}$, showing a significant difference between the two treatments (Fisher's LSD test). Nevertheless, no further change in the total chlorophyll was detected at the end of the recovery period. A reduction in chlorophyll content in coral species was in accordance with a reduction in zooxanthellae density and bleaching (Supplementary Figure 1). Total chlorophylls in seagrasses exhibited differences according to temperature (factorial ANOVA, $p<0.001)$ and species $(p<0.001)$. At the end 


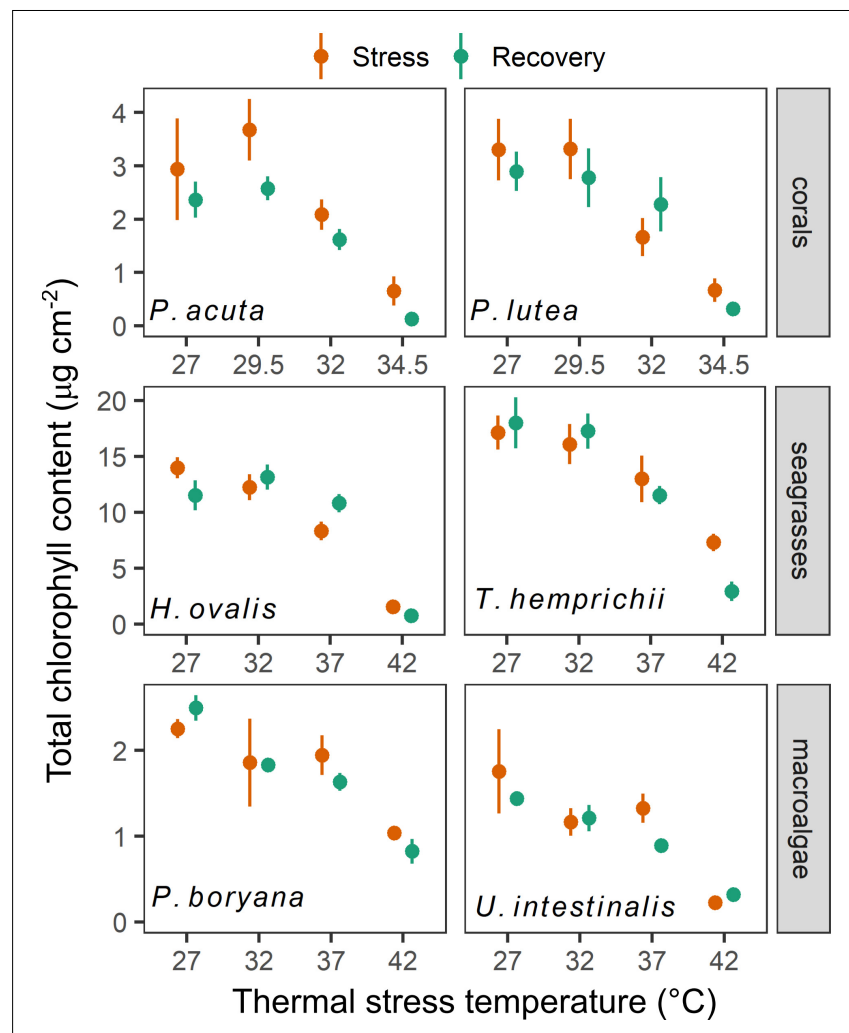

FIGURE 4 | The effects of experimental temperatures on total chlorophyll content of corals, seagrasses and macroalgae at the end of stress and recovery periods. Values are shown as mean $\pm \operatorname{SE}(n=3)$. For each replicate, 3 individuals were sampled. Corals were subjected to $27-34.5^{\circ} \mathrm{C}$ in stress period and $27^{\circ} \mathrm{C}$ in recovery period. Seagrasses and macroalgae were subjected to $27-42^{\circ} \mathrm{C}$ in stress period and $32^{\circ} \mathrm{C}$ in recovery period.

of the stress period, a decrease in total chlorophyll in $H$. ovalis was found at 37 and $42^{\circ} \mathrm{C}$ (Fisher's LSD test). A recovery was observed in the plants exposed to $37^{\circ} \mathrm{C}$. At the end of the stress period, a decrease in total chlorophyll in $T$. hemprichii was found only at $42^{\circ} \mathrm{C}$, which showed a further decline at the end of the recovery period (Fisher's LSD test). Total chlorophylls in macroalgae exhibited differences according to temperature (factorial ANOVA, $p<0.001)$ and species $(p<0.001)$. Both macroalgae showed a significant decrease in total chlorophyll only at $42^{\circ} \mathrm{C}$ treatment (Fisher's LSD test). While $P$. boryana showed no significant change in total chlorophyll at the end of the recovery period, a further decline in the total chlorophyll was detected in U. intestinalis pre-exposed to $37^{\circ} \mathrm{C}$ (Fisher's LSD test).

\section{Growth Rates and Growth-Related Attributes}

Growth rates of all species were affected by increasing temperature (Figure 5). Growth rates of the corals (Figure 5A) were influenced by species (repeated ANOVA, $p<0.05$ ), temperature $(p<0.01)$, time of measurement $(p<0.001)$, and interactions between these factors $(p<0.001)$. At the end of the stress period, the net biomass increments of $P$. acuta exposed to $27,29.5$, and $32^{\circ} \mathrm{C}$ remained similar, whereas a significant decline was observed in individuals exposed to $34.5^{\circ} \mathrm{C}$ (Fisher's LSD test). At this temperature, $P$. acuta exhibited a net loss in biomass. No significant change was detected after the recovery period. On the other hand, the growth rates of $P$. lutea showed a stepwise decline at $27-34.5^{\circ} \mathrm{C}$ (Fisher's LSD test), reaching negative values at $34.5^{\circ} \mathrm{C}$ indicating a net loss in biomass. Complete recovery was seen in individuals pre-exposed to 29.5 and $32^{\circ} \mathrm{C}$, whereas growth rates of the individuals pre-exposed to $34.5^{\circ} \mathrm{C}$ did not improve.

The growth rates in seagrasses (Figure 5B) showed differences according to species (repeated ANOVA, $p<0.01$ ), temperature $(p<0.001)$, time of measurement $(p<0.001)$, and interactions between these factors $(p<0.001)$. The biomass increments of $H$. ovalis measured at the end of the stress period decreased linearly with increasing temperature from 27 to $42^{\circ} \mathrm{C}$ (Fisher's LSD test). Further reductions in growth rates were detected in plants pre-exposed to $27^{\circ} \mathrm{C}$ at the end of the recovery period (Fisher's LSD test). On the contrary, negative effects of temperature on biomass increments of $T$. hemprichii were detected only at $42^{\circ} \mathrm{C}$ (Fisher's LSD test). Further reductions in biomass increments were detected in individuals pre-exposed to 37 and $42^{\circ} \mathrm{C}$ at the end of the recovery period (Fisher's LSD test). In addition, a negative effect of moderate warming $\left(37^{\circ} \mathrm{C}\right)$ was also seen in senescence rates in $T$. hemprichii, which was alleviated after the recovery period (Figure $5 \mathrm{C}$ ). The highest senescence rates were found in $H$. ovalis at $42^{\circ} \mathrm{C}$, which was likely due to mortality.

The growth rates in macroalgae (Figure 5D) showed differences according to temperature (repeated ANOVA, $p<0.001)$, species $(p<0.01)$, and interaction of the two factors $(p<0.001)$. At the end of the stress period, the net biomass increments of $P$. boryana exposed to 27 and $32^{\circ} \mathrm{C}$ were comparable, whereas a net loss in biomass was observed at 37 and $42^{\circ} \mathrm{C}$ (Fisher's LSD test). No significant change was detected after the recovery period. On the other hand, a negative effect of increasing temperature on growth rates of $U$. intestinalis was detected only at $42^{\circ} \mathrm{C}$ (Fisher's LSD test), where there was a net loss in biomass (Figure 5D). In the recovery period, $U$. intestinalis pre-exposed to $37^{\circ} \mathrm{C}$ suffered a further decline in growth, resulting in a net loss in biomass (Fisher's LSD test).

\section{Integrated Biomarker Response}

For all categories, the most sensitive species to increases in temperature were $P$. lutea, $H$. ovalis, and $P$. boryana, as indicated by higher IBR index at 32 and $34.5^{\circ} \mathrm{C}$ for coral and at 37 and $42^{\circ} \mathrm{C}$ for seagrass and macroalga. There was recovery at 37 and $32^{\circ} \mathrm{C}$ only in $H$. ovalis and $P$. lutea, while all species showed no recovery capacity after exposure to the highest temperatures (Figure 6A). The most responsive biomarkers during the stress period were growth in $P$. lutea, $H$. ovalis, and $P$. boryana and chlorophyll content in P. acuta, T. hemprichii, and U. intestinalis. The most responsive biomarkers during the recovery period were growth in $P$. acuta, $H$. ovalis, and $P$. boryana and chlorophyll content in $P$. lutea, T. hemprichii, and $U$. intestinalis. On the other hand, $\underline{F}_{\mathrm{V}} / F_{\mathrm{m}}$ was a less responsive biomarker during the stress and recovery period in all species (Figure 6B). 


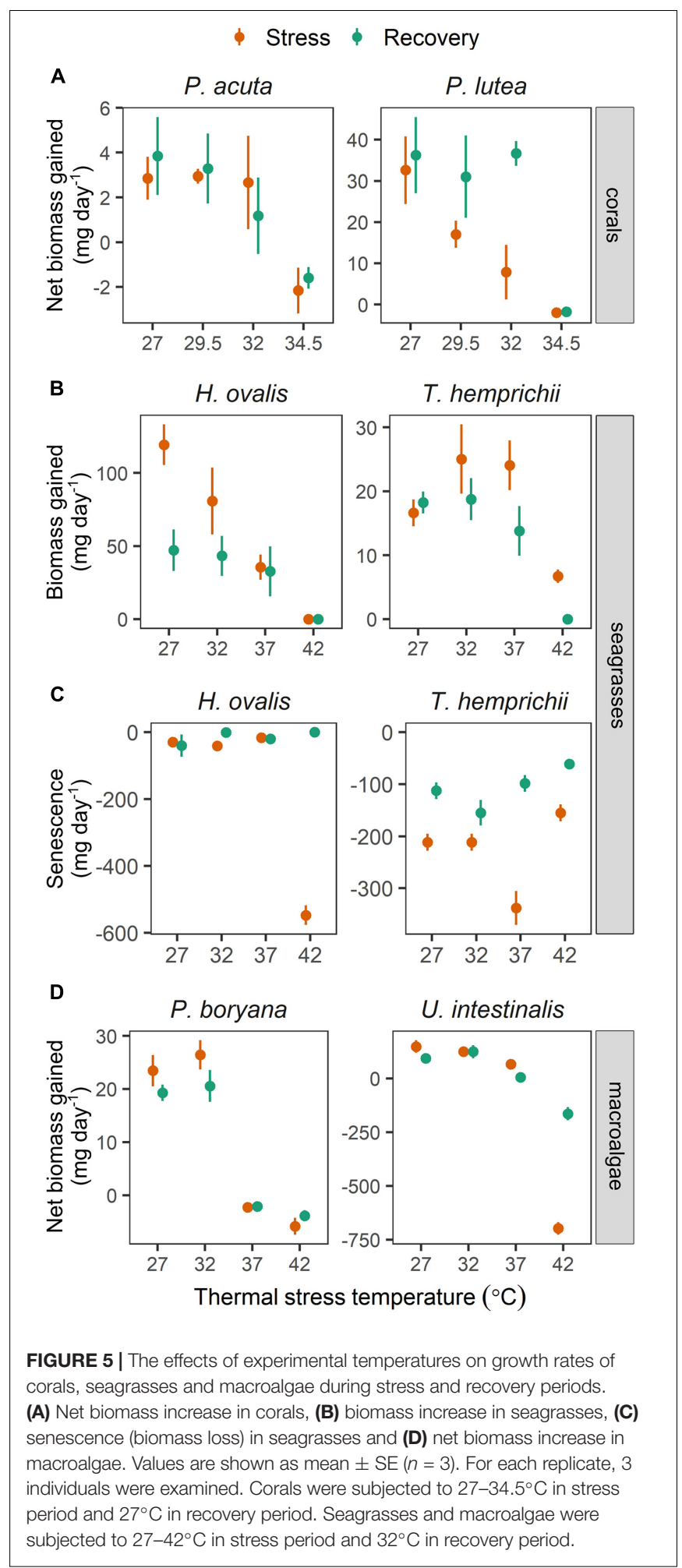

\section{DISCUSSION}

Under warming scenarios, seagrasses and macroalgae could outcompete shallow-water corals, owing to their greater thermal tolerance (Anton et al., 2020; Roth et al., 2021). While the present study supports this notion, our results also show that temperature extremes could affect the photosynthesis and growth of seagrasses and macroalgae, resulting in irrecoverable damage and mortality. IBR provides further support that warming imposes an impact of manifold magnitude on the overall health of the tested species, depending on the temperature. As vulnerability to warming varies both among groups of organisms and species, ECEs are expected to have consequences on the structure, functions, and processes of coastal ecosystems.

\section{Effects of Warming on Overall Performance of Shallow-Water Marine Organisms}

In line with previous studies (Robison and Warner, 2006; Sinutok et al., 2012; Collier and Waycott, 2014; Rasmusson et al., 2020; Danaraj et al., 2021), our results suggest that short duration of elevated temperature poses significant adverse effects on the tropical shallow-water corals, seagrasses, and macroalgae. The heat stress effects, though complex, were manifested as lower efficiency of photosynthesis and photoprotection, chlorophyll degradation, slower growth, and mortality. Our results suggested that heat stress threshold lies between 37 and $42^{\circ} \mathrm{C}$ in seagrasses and macroalgae and between 32 and $34.5^{\circ} \mathrm{C}$ in corals, where the photosynthetic performance and growth were significantly affected. Our results are comparable to the thermal optima and threshold in tropical shallow-water organisms reported in previous studies (Mayfield et al., 2013; Collier et al., 2014; Buerger et al., 2015; Kong et al., 2019; George et al., 2020; Rasmusson et al., 2020, 2021; Keng et al., 2021).

It is established that photosynthesis is a major target of heat stress, since its associated components are heat sensitive (Allakhverdiev et al., 2008). Based on $F_{\mathrm{v}} / F_{\mathrm{m}}$ and $F_{\mathrm{v}} / F_{0}$, corals showed partial photoinhibition at $32^{\circ} \mathrm{C}$, with subsequent recovery and irreversible photodamage at $34.5^{\circ} \mathrm{C}$. On the contrary, the effect of increasing temperature on seagrass and macroalgae went from no effect or a slightly positive effect from 27 to $37^{\circ} \mathrm{C}$ to an acute and lethal effect at $42^{\circ} \mathrm{C}$. These were accompanied by a decrease in RLC-derived parameters $\left(\mathrm{ETR}_{\max }\right.$, $E_{\mathrm{k}}$, and $\left.\alpha\right)$ and chlorophylls contents, indicating an overall decline in photosynthetic activity. As an increase in temperature from 27 to $42^{\circ} \mathrm{C}$ can lead to a significant reduction in $\mathrm{HCO}_{3}{ }^{-}$in seawater (Pierrot et al., 2006), such $\mathrm{HCO}_{3}{ }^{-}$limitation may also contribute to a decrease in photosynthetic activities and growth rates observed in this study, particularly in $\mathrm{HCO}_{3}{ }^{-}$users (Beer and Rehnberg, 1997; Sinutok et al., 2011, 2012). The impacts on photosynthetic functions were worsened with the experimental duration, indicating accumulative stress effects. It is worth noting that $F_{\mathrm{v}} / F_{0}$, although showed higher variability, provided a more sensitive indication of heat stress, which is in agreement with the recent study by Rasmusson et al. (2020), in which $F_{\mathrm{v}} / F_{0}$ instead of $F_{\mathrm{v}} / F_{\mathrm{m}}$ was adopted to trace the effects of warming in temperate and tropical seagrasses. In addition, a decrease in chlorophyll content implies that the ability of the photosynthetic tissue to absorb light also decreased. By using constant absorption factor (AF), the ETR values in RLC fittings were likely to be over-estimated. Direct comparison of ETR $\mathrm{max}_{\max }$ across treatments 
A
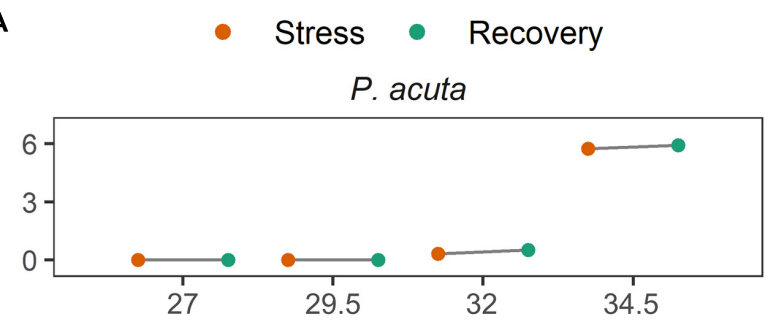

P. lutea

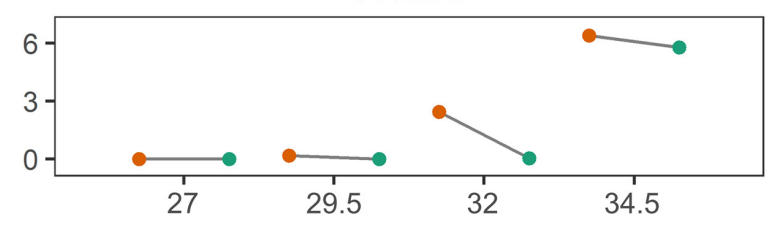

H. ovalis

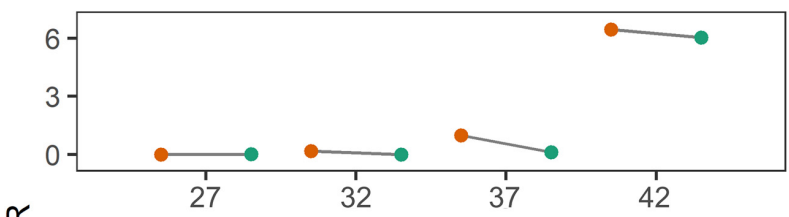

$\underline{\underline{x}}$
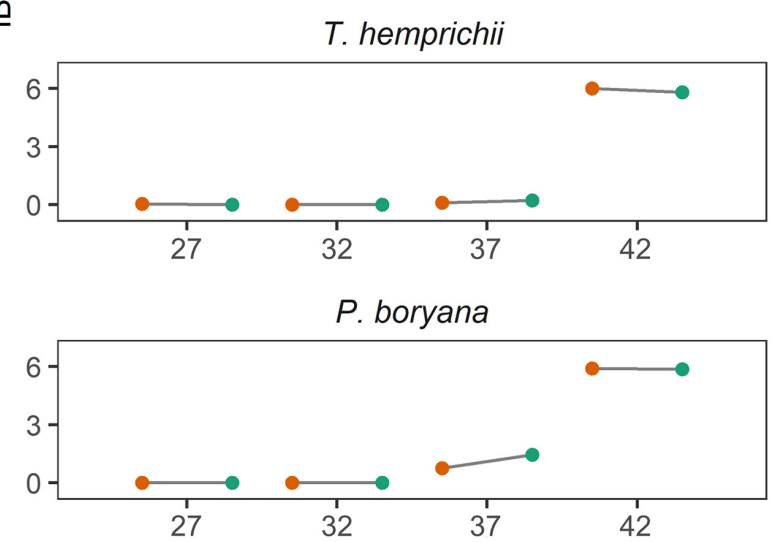

U. intestinalis

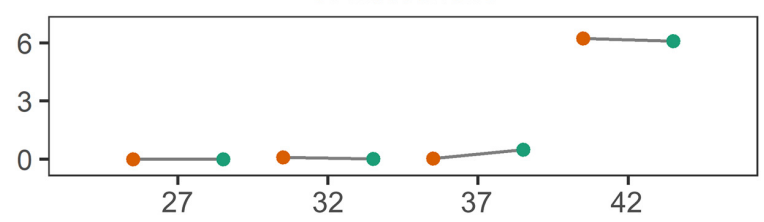

Thermal stress temperature $\left({ }^{\circ} \mathrm{C}\right)$
B
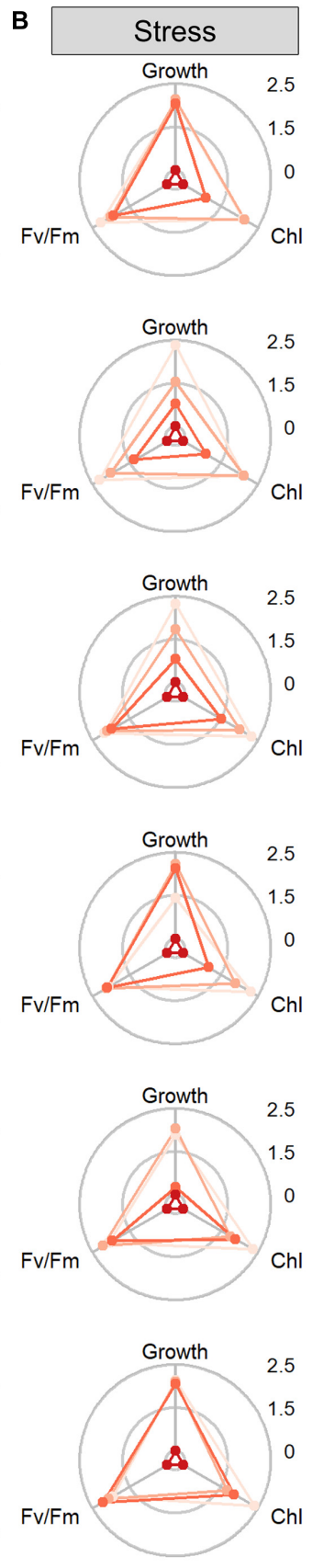
$\begin{array}{cc}\text { Corals: } & 27^{\circ} \mathrm{C} \\ \text { Seagrasses \& } & 27^{\circ} \mathrm{C} \\ \text { Macroalgae: } & \end{array}$

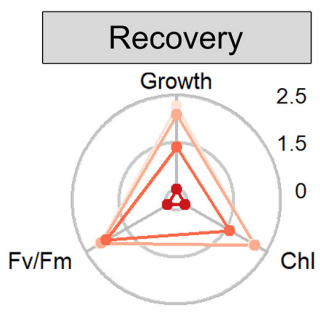

§
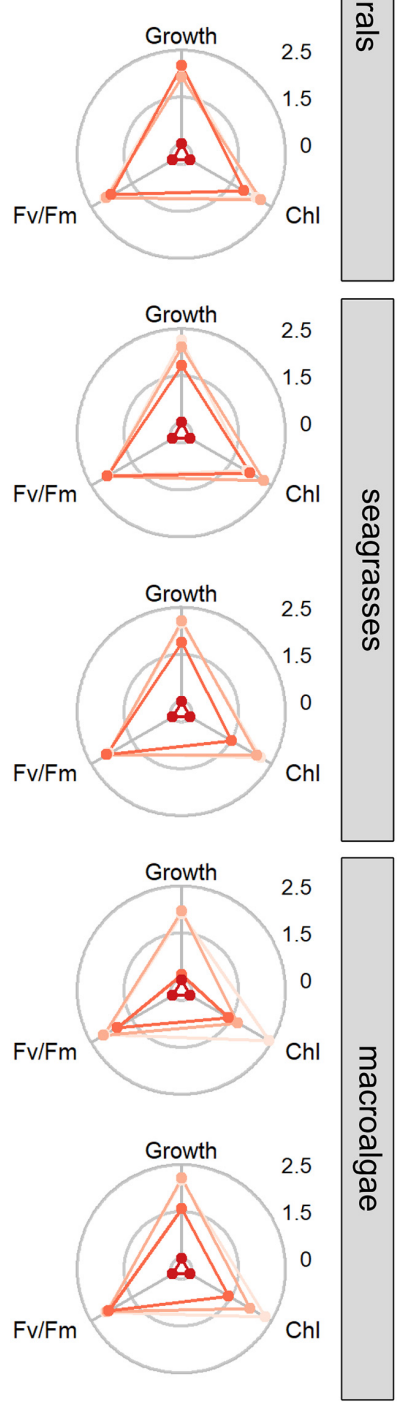

Growth

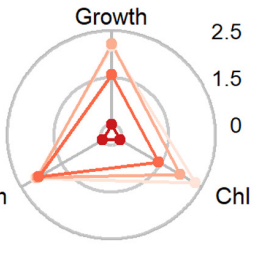

$\mathrm{Fv} / \mathrm{Fm}$

$\begin{aligned} & 29.5^{\circ} \mathrm{C} \\ & 32^{\circ} \mathrm{C}\end{aligned}-\begin{array}{r}32^{\circ} \mathrm{C} \\ 37^{\circ} \mathrm{C}\end{array}-\begin{aligned} & 34.5^{\circ} \mathrm{C} \\ & 42^{\circ} \mathrm{C}\end{aligned}$

FIGURE 6 | (A) The effects of experimental temperatures on the integrated biomarker response (IBR) indices calculated from $F_{\mathrm{v}} / F_{\mathrm{m}}$, chlorophyll contents and growth rates of corals, seagrasses and macroalgae. (B) Star plots with mean scores for $F_{\mathrm{v}} / F_{\mathrm{m}}$, chlorophyll contents and growth rates in all tested species. Chl total chlorophyll content. Growth - growth rates measured as an increase in biomass. Corals were subjected to $27-34.5^{\circ} \mathrm{C}$ in stress period and $27^{\circ} \mathrm{C}$ in recovery period. Seagrasses and macroalgae were subjected to $27-42^{\circ} \mathrm{C}$ in stress period and $32^{\circ} \mathrm{C}$ in recovery period.

(Table 1) should be interpreted with care as heat stress may have more pronounced effects on ETR than reported in our results. This points to limitation of the use of RLCs in repeated measurements in experiment which may induce variation in AF, in line with previous discussions by Enríquez and Borowitzka (2010) and González-Guerrero et al. (2021).

Negative effects were also observed in growth rates of all the tested organisms, which appeared to be more heat 
sensitive than photosynthesis. This may be linked to the negative carbon balance caused by higher respiratory carbon consumption relative to photosynthetic carbon assimilation (Scheufen et al., 2017; Hammer et al., 2018; Rasmusson et al., 2020; Costa et al., 2021), while photorespiratory activity, a competing process with carbon fixation, is known to be enhanced by increased temperature (Zhang et al., 2018; Hu et al., 2020). In addition, metabolic depression and energy allocation to certain defensive mechanisms (Bernardet et al., 2019; Marín-Guirao et al., 2019; Innis et al., 2021) may have long-term consequences on energetic balance and growth. Previous studies highlight that maintaining metabolic balance in coral holobionts (host, symbiotic algae, and associated microbes) is crucial under stress conditions (Levas et al., 2013). Undoubtedly, energy deficiency could be exacerbated during bleaching in corals (Innis et al., 2021), which was visible at $34.5^{\circ} \mathrm{C}$. As coral calcification is known to be tightly coupled with photosynthetic and carbon translocation rates (Tremblay et al., 2016), a decrease in integrated photosynthetic capacity (photodamage, chlorophyll content, and zooxanthellae density) is likely to be among the key drivers for a decline in growth rates in the two corals at this temperature.

A more prominent heat stress effects on growth rates than on photosynthesis was also reported in other tropical species (Sinutok et al., 2012; Terada et al., 2016), including P. acuta, and T. hemprichii (George et al., 2018; Poquita-Du et al., 2020; Ho et al., 2021). This implies that the general notion that photosynthesis is one of the most sensitive physiological processes (Bhagooli et al., 2021) and that its response may precede the response at growth level may not entirely hold true for heat stress or could not be supported by the chlorophyll fluorescence parameters measured in the present study. Tropical shallow-water organisms may be able to maintain an intact photosynthetic machinery during warming events, albeit slower biomass production, which may persist in some species after the warming period is over (e.g., H. ovalis; P. boryana, and $U$. intestinalis at $37^{\circ} \mathrm{C}$ ). In seagrasses, senescence was found to be among the significant effects of warming; not only seen as higher number of dead leaves in the two species, but higher number of shed leaves in T. hemprichii at $37^{\circ} \mathrm{C}$. Anoxia in intercalary meristematic tissue has been identified as among the mechanisms contributing to detachment of shoots in seagrasses subjected to heat stress (Hammer et al., 2018). From our results, we proposed that whole-organism-related parameters, such as growth rates and senescence, may serve as good measurements for heat stress responses in relatively fast-growing species. These parameters are not only quantifiable but also ecologically relevant since they give an integrated indication of the organism's performance and health status (Madeira et al., 2018; Dias et al., 2020).

\section{Differences in Sensitivity to Warming Among Important Groups of Tropical Marine Organisms and Species and Its Ecological Relevance}

Different sensitivities to warming in conjunction with biotic interactions are likely to be the key predictors of climate change impacts on shallow-water marine ecosystems. Among the six species from three different groups of organisms, the seagrass T. hemprichii may be the least affected by future warming, whereas the coral $P$. lutea appears to be the most sensitive to increments in temperature.

Coral bleaching and mortality generally occur when the ambient temperature exceeds the thermal thresholds (Skirving et al., 2019). Mass bleaching of shallow-water corals in Thai waters corresponded to the thermal anomalies, with an average SST of $30.1^{\circ} \mathrm{C}$ in 1991 and $1995,30.4^{\circ} \mathrm{C}$ in 1998 , and $31.1^{\circ} \mathrm{C}$ in 2010 and 2016 (Brown et al., 1996; Phongsuwan and Chansang, 2012; Sutthacheep et al., 2013b; Putchim et al., 2017). In addition, a long-term comparative study conducted in Phuket in 1984-1986 and 2003-2005 revealed that a gradual increase in temperature resulted in a significant reduction in skeletal growth of the coral P. lutea (Tanzil et al., 2009). The average SSTs showed an increasing trend during the past three decades (Brown et al., 1996; Tanzil et al., 2009; Phongsuwan and Chansang, 2012; Sutthacheep et al., 2013b; Putchim et al., 2017) and is expected to reach $32^{\circ} \mathrm{C}$ in the near future (Hoegh-Guldberg et al., 2018). Our field records of variability in temperatures in the natural setting indicate that shallow-water corals are already exposed to an occasional rise in ambient temperature to $32^{\circ} \mathrm{C}$ (Unpublished data by authors). The future scenarios may drive radical change of local reef structure as recorded in the Great Barrier Reef (Hughes et al., 2018). Such higher thermal sensitivity observed in corals compared to seagrasses and macroalgae might be because they often grow in deeper habitats, thus experiencing smaller fluctuations in temperature and are rarely exposed during low tide (Smale et al., 2019; Roth et al., 2021). Although seagrasses and macroalgae can withstand a wide range of increasing temperature, a rapid deleterious effect was observed when the testing temperature reached $42^{\circ} \mathrm{C}$, implying that the irregular warming events, in which temperature rises above $40^{\circ} \mathrm{C}$, though uncommon and brief, will put immense pressure on intertidal seagrasses and macroalgae, thereby affecting productivity and leading to mortality. Although the seagrass and macroalgal dieoff as a result of warming event was never reported in Thailand, it has been recorded in other locations in the tropical bioregions (Carlson et al., 2018; Buckee et al., 2021).

It is therefore expected that, as a result of moderate warming, seagrasses and macroalgae could outcompete shallow-water corals as the temperature increases (Anton et al., 2020; Roth et al., 2021). Although our results suggest that T. hemprichii might be the most persistent species in warming scenarios because of their relatively high thermotolerance, successful expansion, and colonization in the subtidal areas requires acclimation to different arrays of environmental factors (Beca-Carretero et al., 2020). One of the key limiting factors is light availability, which has been identified as the fundamental driver for growth and distribution of many marine primary producers (Falkowski and Knoll, 2007). Due to their relatively higher light requirement, slower growth rate, and preference for soft substrates (Collier et al., 2012; Badalamenti et al., 2015), seagrasses are less likely to expand to deeper coral reef areas, implying that direct interaction between corals and seagrasses is improbable. On the contrary, there is growing evidence of enhanced algal occupation of coral reefs following warming events (Hughes et al., 2019; 
Anton et al., 2020; Wasim et al., 2021). This interaction with macroalgae has been shown to worsen coral health status and physiological performance and is often associated with coral reef degradation (Fong and Todd, 2021; Roth et al., 2021). Although they appear less tolerant to extreme warming, opportunistic characteristics, such as rapid nutrient uptake, effective carbon utilization, and high reproduction capacity of Ulva species and their free-floating trait (Buapet et al., 2008, 2013; Zhang et al., 2019; Kambey et al., 2020), may allow them to proliferate in the coral reef habitat under moderate warming scenarios, particularly where eutrophication is not properly regulated. As previously stated, light is one of the key controlling factors (Falkowski and Knoll, 2007) and studies have shown that interaction with light availability can determine heat stress responses in marine species (Dove et al., 2006; Moreno-Marín et al., 2018; Costa et al., 2021). The extrapolation of our results obtained from controlled experiment using a single nonphotoinhibitory level of irradiance to natural conditions, where organisms are exposed to different light environments, must be taken with caution.

When comparing the two species of corals, $P$. acuta maintained their photosynthesis and growth rates relatively well when facing moderate heat stress $\left(29.5-32^{\circ} \mathrm{C}\right)$, although more rapid bleaching (Supplementary Figure 1) and earlier mortality were observed in $34.5^{\circ} \mathrm{C}$ compared to $P$. lutea. Other biological attributes, such as photosynthetic efficiency and growth rates, suggested that $P$. lutea was more sensitive to warming, particularly at moderate levels. It has been suggested that Pocillopora species are more susceptible to thermal stress than the massive Porites species (Hill et al., 2012). This is evident in the mass coral bleaching events from 1998 to 2010 during which severe bleaching and mortality of pocilloporids in Thai waters were recorded (Yeemin et al., 2009; Chavanich et al., 2012; Sutthacheep et al., 2013b). Nevertheless, their susceptibility seems to reduce as they were repeatedly exposed to thermal stress (Pratchett et al., 2013; McClanahan, 2017; Putchim et al., 2017). Association with Clade D types of zooxanthellae, a more heatresistant clade, which have been increasingly reported in Thai coastal reefs (Chankong et al., 2018, 2020), may contribute to their enhanced thermotolerance (Cunning et al., 2015; Wham et al., 2017). On the contrary, field records showed that $P$. lutea often suffered partial bleaching and mortality (Phongsuwan and Chansang, 2012; Brown et al., 2014) and that this phenomenon has gradually increased during the past decade (Putchim et al., 2017). Significant impacts of warming on Porites species were manifested as a decline in calcification measured as linear extension, density, and hiatus (Cantin and Lough, 2014; Xu et al., 2018), which is in line with our results. It is worth noting that growth rates of $P$. lutea pre-exposed to $32^{\circ} \mathrm{C}$ displayed complete recovery, thus corroborating previous investigations reporting the subsequent recovery of $P$. lutea after thermal stress in their natural settings (Phongsuwan and Chansang, 2012; Brown et al., 2014).

The different life traits of the two seagrasses may contribute to their difference in thermotolerance. Halophila are considered the colonizing species, while Thalassia are considered the persistent ones (Kilminster et al., 2015; O’Brien et al., 2018). It has been suggested that the former often exhibit lower physiological resistance to environmental disturbances compared to the latter (Kilminster et al., 2015; O’Brien et al., 2018). This notion agrees with the findings in the present study and is in line with our previous investigations in which $H$. ovalis showed lower physiological tolerance to stressors, such as desiccation and high irradiance, than T. hemprichii (Wuthirak et al., 2016; Phandee and Buapet, 2018). Nevertheless, colonizing species are expected to recover from stress more rapidly than persistent species, owing to their fast growth rates and usually large seed banks (Kilminster et al., 2015; O’Brien et al., 2018; Ong et al., 2020). Even at a short duration of recovery, physiological improvement was already seen in $H$. ovalis exposed to $37^{\circ} \mathrm{C}$. In this study, while growth rates were not yet restored, their photosynthesis and chlorophyll contents showed almost complete recovery after 5 days at optimal temperature.

Padina species are lightly-calcified brown macroalgae (Wichachucherd et al., 2010), whereas Ulva species are green macroalgae known for their opportunistic traits and capacity to generate "green tides" (Zhang et al., 2019; Kambey et al., 2020). Higher thermotolerance in $U$. intestinalis compared to $P$. boryana may be a result of their local acclimation. In their respective sampling sites, $U$. intestinalis were mostly found free-floating or attached to seagrass leaf blades or mangrove roots and directly exposed to sunlight and heat at low tide, while $P$. boryana remained attached to the substrate, forming assemblage structure, which may buffer drastic changes in environmental factors influenced by tidal cycle. Underlying mechanisms of heat tolerance in Ulva species have been extensively studied and vast arrays of molecular regulations and metabolic adjustment pathways have been identified (Fan et al., 2017; He et al., 2018). Previous studies also provide evidence that calcified macroalgae are more negatively affected by warming than fleshy macroalgae (Kram et al., 2016; Dove et al., 2020), partly due to the sensitivity of the calcification process to heat (Sinutok et al., 2011, 2012). Although $P$. boryana and $U$. intestinalis did not show recovery potential after 5 days at optimal temperature, both species have high reproductive outputs and high recruitment potential (Wichachucherd et al., 2010; Mayakun, 2019), which may support their long-term recolonization once the environmental factors become favorable.

Devastating loss of ecosystem services are expected if the corals, seagrasses, and macroalgae undergo degradation. As Porites and Pocillopora species serve as dominant reefbuilding corals in Thai waters (Yeemin et al., 2009; Chavanich et al., 2012; Sutthacheep et al., 2013b; Putchim et al., 2017), negative effects on their productivity and growth may be translated to an overall decrease in the health of coral habitats, thereby affecting a range of services, such as nursery ground (Lin et al., 2021), fisheries (Edgar et al., 2014), and coastal protection (Zhao et al., 2019). In addition to these services, seagrass meadows and some macroalgal habitats contribute as effective sinks for $\mathrm{CO}_{2}$ (Krause-Jensen and Duarte, 2016), and their decline would eventually reduce the overall capacity for carbon sequestration and promote a release of greenhouse gasses (Arias-Ortiz et al., 2018). Thus, the effects 
of warming may not only limit to coastal habitat degradation but may also accelerate the changing climate. While recovery by recolonization is possible, reports suggest that ecosystem services provided by fast-growing pioneer species may differ from those provided by the climax species (Kilminster et al., 2015; O'Brien et al., 2018). Therefore, long-term shifts of structure, functions, and processes of coastal ecosystems may be expected following ECEs.

\section{Integrated Biomarker Response and Application for Monitoring and Management Efforts}

The IBR index was adopted to quantify and visualize an overall integrated stress effect of warming on all shallowwater marine organisms. This tool has been successfully applied in assessing the health of corals, reef calcifiers, and marine invertebrates exposed to climate change related stressors, including warming (Madeira et al., 2018; Dias et al., 2020; Marques et al., 2020; Zhang et al., 2021); however, its application in seagrass and macroalgal research is yet to be explored. It is established that various biomarkers at different biological organization levels, ranging from cellular to organismal levels, are affected by increasing temperatures (George et al., 2018; Madeira et al., 2018; Savva et al., 2018; Dias et al., 2020). Early investigations on corals and other marine invertebrates also suggested that biomarkers both associated with cellular mechanisms and whole-organism performance should be combined in IBR indices to better elucidate the effects of heat stress (Madeira et al., 2018; Dias et al., 2020). Therefore, we tested the IBR approach using $F_{\mathrm{v}} / F_{\mathrm{m}}$, chlorophyll content, and growth rate as biomarkers encompassing physiological, biochemical, and organismal responses, respectively.

In general, the IBR index increased with increasing temperature in all tested organisms (Figure 6A). The highest IBR index was found at $34.5^{\circ} \mathrm{C}$ in corals and at $42^{\circ} \mathrm{C}$ in seagrasses and macroalgae, which indicates the highest stress level at this temperature. These integrative analyses, which corroborate the previously discussed results, indicate that an increase of $2.5^{\circ} \mathrm{C}$ from the maximum SST $\left(32^{\circ} \mathrm{C}\right)$ will produce lethal effects in corals, while an increase of $10^{\circ} \mathrm{C}$ from the maximum SST will potentially cause seagrasses and macroalgae to die-off. In addition, a slightly higher IBR value was observed at $32^{\circ} \mathrm{C}$ in the coral $P$. lutea and at $37^{\circ} \mathrm{C}$ in the seagrass $H$. ovalis and the macroalga $P$. boryana, thus suggesting a higher sensitivity of these species under moderate heat stress. Therefore, poorer health of these organisms may be already seen within a range of the current maximum SST to an increase in the maximum SST by $5^{\circ} \mathrm{C}$. Recovery from five consecutive days of moderate heat stress, however, was observed in P. lutea and $H$. ovalis, implying that the overall health status can be restored once the warming period is over. This emphasizes that the ability of the organisms to recover from stress significantly contributes to their resilience to moderate warming (Brown et al., 2014; Xu et al., 2020; Nguyen et al., 2021) and that recovery should be considered when evaluating the potential impacts of ECEs.

The IBR analysis showed an inhibition of photosynthetic activity, degradation of chlorophyll, and slower growth in all the tested species (Figure 6B). Deleterious effects at $34.5^{\circ} \mathrm{C}$ for corals and $42^{\circ} \mathrm{C}$ for seagrasses and macroalgae were manifested as a marked decline of all three biomarkers, while sublethal effects $\left(32^{\circ} \mathrm{C}\right.$ in the corals and $37^{\circ} \mathrm{C}$ in the seagrasses and macroalgae) were largely driven by growth rate and chlorophyll content for most of the tested species. These results, which support the suggestions made by previous studies (Madeira et al., 2018; Dias et al., 2020; Marques et al., 2020; Zhang et al., 2021), highlight the importance of using multiple biomarkers across the biological organizations and inclusion of the biomarkers at the organismic level.

Our results demonstrate that the IBR approach provides quantifiable indices for monitoring the health status of shallowwater marine organisms under warming scenarios and is therefore proven a useful tool for both research and management. Nevertheless, improvement of its efficiency is warranted, and careful consideration is necessary when interpreting the results within complex environments of a natural setting. While the biomarker suite adopted in the present study seems sufficient to elucidate the overall stress effects in the tested species, since it displayed a temperature-dependent response, all biomarkers are not specific to heat stress. Incorporations of biomarkers, such as heat shock proteins, energy metabolismsrelated makers, and certain regulatory molecules (van Oppen and Oakeshott, 2020; Danaraj et al., 2021; Innis et al., 2021), particularly those at the molecular level, will enhance the precision and resolution of the IBR index. However, the selection of suitable biomarkers relies on advanced knowledge of the cause-effect relationship between temperature and complex biological responses of given species and populations, which remains inadequate, particularly in the tropical Southeast Asian region (Guan et al., 2020; Nguyen et al., 2021). An in-depth understanding of the underlying physiological mechanisms associated with warming will therefore not only be crucial for predicting how future warming scenarios will affect the coastal ecosystems, but also for developing a more effective tool to assess and mitigate the long-term impact of warming events on shallowwater marine organisms.

\section{DATA AVAILABILITY STATEMENT}

The raw data supporting the conclusions of this article will be made available by the authors, without undue reservation.

\section{AUTHOR CONTRIBUTIONS}

All authors contributed to the conceptualization of the study. MY, SS, PC, and PB planned and conducted the experiments, analyzed the samples, interpreted the data, performed the statistical analysis, and wrote the manuscript. All authors read and approved the submitted manuscript. 


\section{FUNDING}

This research was supported by National Science, Research and Innovation Fund (NSRF) and Prince of Songkla University (Grant Number: ENV6405083M).

\section{ACKNOWLEDGMENTS}

The authors wish to thank Jenjira Sudprang, Chutima Tongchu, Pimrak Moungkeaw, and Long Ying for their helpful

\section{REFERENCES}

Allakhverdiev, S. I., Kreslavski, V. D., Klimov, V. V., Los, D. A., Carpentier, R., and Mohanty, P. (2008). Heat stress: an overview of molecular responses in photosynthesis. Photosynth. Res. 98, 541-550. doi: 10.1007/s11120-008-9331-0

Anton, A., Randle, J. L., Garcia, F. C., Rossbach, S., Ellis, J. I., Weinzierl, M., et al. (2020). Differential thermal tolerance between algae and corals may trigger the proliferation of algae in coral reefs. Glob. Chang. Biol. 26, 4316-4327. doi: $10.1111 /$ gcb.15141

Arias-Ortiz, A., Serrano, O., Masqué, P., Lavery, P. S., Mueller, U., Kendrick, G. A., et al. (2018). A marine heatwave drives massive losses from the world's largest seagrass carbon stocks. Nat. Clim. Chang. 8, 338-344. doi: 10.1038/s41558-0180096-y

Badalamenti, F., Alagna, A., and Fici, S. (2015). Evidences of adaptive traits to rocky substrates undermine paradigm of habitat preference of the Mediterranean seagrass Posidonia oceanica. Sci. Rep. 5:8804. doi: 10.1038/srep08804

Beca-Carretero, P., Teichberg, M., Winters, G., Procaccini, G., and Reuter, H. (2020). Projected rapid habitat expansion of tropical seagrass species in the Mediterranean Sea as climate change progresses. Front. Plant Sci. 11:555376. doi: $10.3389 /$ fpls.2020.555376

Beer, S., and Rehnberg, J. (1997). The acquisition of inorganic carbon by the seagrass Zostera marina. Aquat. Bot. 56, 277-283. doi: 10.1016/S0304-3770(96) 01109-6

Beliaeff, B., and Burgeot, T. (2002). Integrated biomarker response: a useful tool for ecological risk assessment. Environ. Toxicol. Chem. 21, 1316-1322. doi: 10.1002/etc.5620210629

Bernardet, C., Tambutté, E., Techer, N., Tambutté, S., and Venn, A. A. (2019). Ion transporter gene expression is linked to the thermal sensitivity of calcification in the reef coral Stylophora pistillata. Sci. Rep. 9:18676. doi: 10.1038/s41598-01954814-7

Bhagooli, R., Mattan-Moorgawa, S., Kaullysing, D., Louis, Y. D., Gopeechund, A., Ramah, S., et al. (2021). Chlorophyll fluorescence-a tool to assess photosynthetic performance and stress photophysiology in symbiotic marine invertebrates and seaplants. Mar. Pollut. Bull. 165:112059. doi: 10.1016/j. marpolbul.2021.112059

Brown, B. E., Dunne, R. P., and Chansang, H. (1996). Coral bleaching relative to elevated seawater temperature in the Andaman Sea (Indian Ocean) over the last 50 years. Coral Reefs 15, 151-152. doi: 10.1007/BF01145885

Brown, B. E., Dunne, R. P., Phongsuwan, N., Patchim, L., and Hawkridge, J. M. (2014). The reef coral Goniastrea aspera: a 'winner' becomes a 'loser' during a severe bleaching event in Thailand. Coral Reefs 33, 395-401. doi: 10.1007/ s00338-013-1120-3

Buapet, P., Hiranpan, R., Ritchie, R. J., and Prathep, A. (2008). Effect of nutrient inputs on growth, chlorophyll, and tissue nutrient concentration of Ulva reticulata from a tropical habitat. Sci. Asia 34:245. doi: 10.2306/scienceasia15131874.2008.34.245

Buapet, P., Rasmusson, L. M., Gullström, M., and Björk, M. (2013). Photorespiration and carbon limitation determine productivity in temperate seagrasses. PLoS One 8:e83804. doi: 10.1371/journal.pone.0083804

Buckee, J., Hetzel, Y., Nyegaard, M., Evans, S., Whiting, S., Scott, S., et al. (2021). Catastrophic loss of tropical seagrass habitats at the Cocos (Keeling) islands due to multiple stressors. Mar. Pollut. Bull. 170:112602. doi: 10.1016/j.marpolbul. 2021.112602 assistance in the laboratory and Michael Jenke for support in data visualization.

\section{SUPPLEMENTARY MATERIAL}

The Supplementary Material for this article can be found online at: https://www.frontiersin.org/articles/10.3389/fmars. 2021.767628/full\#supplementary-material

Buerger, P., Schmidt, G. M., Wall, M., Held, C., and Richter, C. (2015). Temperature tolerance of the coral Porites lutea exposed to simulated large amplitude internal waves (LAIW). J. Exp. Mar. Biol. Ecol. 471, 232-239. doi: 10.1016/j.jembe.2015. 06.014

Cantin, N. E., and Lough, J. M. (2014). Surviving coral bleaching events: porites growth anomalies on the Great Barrier Reef. PLoS One 9:e88720. doi: 10.1371/ journal.pone.0088720

Carlson, D. F., Yarbro, L. A., Scolaro, S., Poniatowski, M., McGee-Absten, V., and Carlson, P. R. (2018). Sea surface temperatures and seagrass mortality in Florida Bay: spatial and temporal patterns discerned from MODIS and AVHRR data. Remote Sens. Environ. 208, 171-188. doi: 10.1016/j.rse.2018.02.014

Cesar, H. S. J., Burke, L. M., and Pet-Soede, L. (2003). The Economics of Worldwide Coral Reef Degradation. Arnhem: Cesar Environmental Economics Consulting (CEEC).

Chankong, A., Kongjandtre, N., Senanan, W., and Manthachitra, V. (2018). Genetic diversity of Symbiodiniaceae associated with Porites lutea and Pocillopora damicornis in the Gulf of Thailand inferred from nucleotide sequences of internal transcribed spacer-2. J. Fish. Environ. 42, 66-79.

Chankong, A., Kongjandtre, N., Senanan, W., and Manthachitra, V. (2020). Community composition of Symbiodiniaceae among four scleractinian corals in the eastern Gulf of Thailand. Reg. Stud. Mar. Sci. 33:100918. doi: 10.1016/j. rsma.2019.100918

Chavanich, S., Viyakarn, V., Adams, P., Klammer, J., and Cook, N. (2012). Reef communities after the 2010 mass coral bleaching at Racha Yai Island in the Andaman Sea and Koh Tao in the Gulf of Thailand. Phuket Mar. Biol. Center Res. Bull. 71, 103-110.

Collier, C. J., and Waycott, M. (2014). Temperature extremes reduce seagrass growth and induce mortality. Mar. Pollut. Bull. 83, 483-490. doi: 10.1016/j. marpolbul.2014.03.050

Collier, C. J., Ow, Y. X., Langlois, L., Uthicke, S., Johansson, C. L., O’Brien, K. R., et al. (2017). Optimum temperatures for net primary productivity of three tropical seagrass species. Front. Plant Sci. 8:1446. doi: 10.3389/fpls.2017.01446

Collier, C. J., Villacorta-Rath, C., van Dijk, K., Takahashi, M., and Waycott, M. (2014). Seagrass proliferation precedes mortality during hypo-salinity events: a stress-induced morphometric response. PLoS One 9:e94014. doi: 10.1371/ journal.pone.0094014

Collier, C. J., Waycott, M., and Ospina, A. G. (2012). Responses of four IndoWest Pacific seagrass species to shading. Mar. Pollut. Bull. 65, 342-354. doi: 10.1016/j.marpolbul.2011.06.017

Colombo-Pallota, M. F., García-Mendoza, E., and Ladah, L. B. (2006). Photosynthetic performance, light absorption, and pigment composition of Macrocystis pyrifera (Laminariales, Phaephyceae) blades from different depths. J. Phycol. 42, 1225-1234. doi: 10.1111/j.1529-8817.2006.00287.x

Costa, M. M., Silva, J., Barrote, I., and Santos, R. (2021). Heatwave effects on the photosynthesis and antioxidant activity of the seagrass Cymodocea nodosa under contrasting light regimes. Oceans 2, 448-460. doi: 10.3390/ oceans 2030025

Cunning, R., Silverstein, R. N., and Baker, A. C. (2015). Investigating the causes and consequences of symbiont shuffling in a multi-partner reef coral symbiosis under environmental change. Proc. R. Soc. B 282:20141725. doi: 10.1098/rspb. 2014.1725

Danaraj, J., Ayyappan, S., Mariasingarayan, Y., Packiyavathy, I. A. S. V., and Dharmadhas, J. S. (2021). Chlorophyll fluorescence, dark respiration and 
metabolomic analysis of Halodule pinifolia reveal potential heat responsive metabolites and biochemical pathways under ocean warming. Mar. Environ. Res. 164:105248. doi: 10.1016/j.marenvres.2020.105248

Davies, P. S. (1989). Short-term growth measurements of corals using an accurate buoyant weighing technique. Mar. Biol. 101, 389-395. doi: 10.1007/ BF00428135

Dias, M., Madeira, C., Jogee, N., Ferreira, A., Gouveia, R., Cabral, H., et al. (2020). Integrative indices for health assessment in reef corals under thermal stress. Ecol. Indic. 113:106230. doi: 10.1016/j.ecolind.2020.106230

Dove, S. G., Brown, K. T., Van Den Heuvel, A., Chai, A., and Hoegh-Guldberg, O. (2020). Ocean warming and acidification uncouple calcification from calcifier biomass which accelerates coral reef decline. Commun. Earth. Environ. 1:55. doi: 10.1038/s43247-020-00054-x

Dove, S., Ortiz, J. C., Enríquez, S., Fine, M., Fisher, P., Iglesias-Prieto, R., et al. (2006). Response of holosymbiont pigments from the scleractinian coral Montipora monasteriata to short-term heat stress. Limnol. Oceanogr. 51, 11491158. doi: 10.4319/lo.2006.51.2.1149

Duarte, B., Martins, I., Rosa, R., Matos, A. R., Roleda, M. Y., Reusch, T. B. H., et al. (2018). Climate change impacts on seagrass meadows and macroalgal forests: an integrative perspective on acclimation and adaptation potential. Front. Mar. Sci. 5:190. doi: 10.3389/fmars.2018.00190

Eakin, C. M., Sweatman, H. P. A., and Brainard, R. E. (2019). The 2014-2017 global-scale coral bleaching event: insights and impacts. Coral Reefs 38, 539545. doi: 10.1007/s00338-019-01844-2

Edgar, G. J., Stuart-Smith, R. D., Willis, T. J., Kininmonth, S., Baker, S. C., Banks, S., et al. (2014). Global conservation outcomes depend on marine protected areas with five key features. Nature 506, 216-220. doi: 10.1038/nature13022

Enríquez, S., and Borowitzka, M. A. (2010). "The use of the fluorescence signal in studies of seagrasses and macroalgae," in Chlorophyll a Fluorescence in Aquatic Sciences: Methods and Applications, eds D. J. Suggett, O. Prášil, and M. A. Borowitzka (Dordrecht: Springer), 187-208.

Falkowski, P. G., and Knoll, A. H. (2007). "An introduction to primary producers in the sea: who they are, what they do, and when they evolved," in Evolution of Primary Producers in the Sea, eds P. G. Falkowski and A. H. Knoll (Amsterdam: Elsevier), 1-6. doi: 10.1016/B978-012370518-1/50002-3

Fan, M., Sun, X., Xu, N., Liao, Z., Li, Y., Wang, J., et al. (2017). Integration of deep transcriptome and proteome analyses of salicylic acid regulation high temperature stress in Ulva prolifera. Sci Rep 7:11052. doi: 10.1038/s41598-01711449-w

Fong, J., and Todd, P. A. (2021). Spatio-temporal dynamics of coral-macroalgal interactions and their impacts on coral growth on urbanised reefs. Mar. Pollut. Bull. 172:112849.

Freeman, L. A., Kleypas, J. A., and Miller, A. J. (2013). Coral reef habitat response to climate change scenarios. PLoS One 8:e82404. doi: 10.1371/journal.pone. 0082404

George, R., Gullström, M., Mangora, M. M., Mtolera, M. S. P., and Björk, M. (2018). High midday temperature stress has stronger effects on biomass than on photosynthesis: a mesocosm experiment on four tropical seagrass species. Ecol. Evol. 8, 4508-4517. doi: 10.1002/ece3.3952

George, R., Gullström, M., Mtolera, M. S. P., Lyimo, T. J., and Björk, M. (2020). Methane emission and sulfide levels increase in tropical seagrass sediments during temperature stress: a mesocosm experiment. Ecol. Evol. 10, 1917-1928. doi: $10.1002 /$ ece3.6009

Gibbin, E. M., Krueger, T., Putnam, H. M., Barott, K. L., Bodin, J., Gates, R. D., et al. (2018). Short-term thermal acclimation modifies the metabolic condition of the coral holobiont. Front. Mar. Sci. 5:10. doi: 10.3389/fmars.2018. 00010

González-Guerrero, L. A., Vásquez-Elizondo, R. M., López-Londoño, T., Hernán, G., Iglesias-Prieto, R., and Enríquez, S. (2021). Validation of parameters and protocols derived from chlorophyll a fluorescence commonly utilised in marine ecophysiological studies. Funct. Plant. Biol. doi: 10.1071/FP21101 [Epub ahead of print].

Good, A. M., and Bahr, K. D. (2021). The coral conservation crisis: interacting local and global stressors reduce reef resiliency and create challenges for conservation solutions. SN Appl. Sci. 3:312. doi: 10.1007/s42452-021-04319-8

Guan, Y., Hohn, S., Wild, C., and Merico, A. (2020). Vulnerability of global coral reef habitat suitability to ocean warming, acidification and eutrophication. Glob. Chang. Biol. 26, 5646-5660. doi: 10.1111/gcb.15293
Hammer, K. J., Borum, J., Hasler-Sheetal, H., Shields, E. C., Sand-Jensen, K., and Moore, K. A. (2018). High temperatures cause reduced growth, plant death and metabolic changes in eelgrass Zostera marina. Mar. Ecol. Prog. Ser. 604, 121-132. doi: 10.3354/meps 12740

He, Y., Hu, C., Wang, Y., Cui, D., Sun, X., Li, Y., et al. (2018). The metabolic survival strategy of marine macroalga Ulva prolifera under temperature stress. J. Appl. Phycol. 30, 3611-3621. doi: 10.1007/s10811-018-1493-3

Henderson, C. J., Stevens, T., Lee, S. Y., Gilby, B. L., Schlacher, T. A., Connolly, R. M., et al. (2019). Optimising seagrass conservation for ecological functions. Ecosystems 22, 1368-1380. doi: 10.1007/s10021-019-00343-3

Hill, R., and Ralph, P. J. (2007). Post-bleaching viability of expelled zooxanthellae from the scleractinian coral Pocillopora damicornis. Mar. Ecol. Prog. Ser. 352, 137-144. doi: 10.3354/meps07159

Hill, R., Brown, C. M., DeZeeuw, K., Campbell, D. A., and Ralph, P. J. (2011). Increased rate of $\mathrm{D} 1$ repair in coral symbionts during bleaching is insufficient to counter accelerated photo-inactivation. Limnol. Oceanogr. 56, 139-146. doi: 10.4319/lo.2011.56.1.0139

Hill, R., Larkum, A. W. D., Prášil, O., Kramer, D. M., Szabó, M., Kumar, V., et al. (2012). Light-induced dissociation of antenna complexes in the symbionts of scleractinian corals correlates with sensitivity to coral bleaching. Coral Reefs 31 , 963-975. doi: 10.1007/s00338-012-0914-z

Ho, M., McBroom, J., Bergstrom, E., and Diaz-Pulido, G. (2021). Physiological responses to temperature and ocean acidification in tropical fleshy macroalgae with varying affinities for inorganic carbon. ICES J. Mar. Sci. 78, 89-100. doi: 10.1093/icesjms/fsaa195

Hoegh-Guldberg, O., Jacob, D., Taylor, M., Bindi, M., Brown, S., Camilloni, I., et al. (2018). "Impacts of $1.5^{\circ} \mathrm{C}$ global warming on natural and human systems," in Global Warming of $1.5^{\circ} \mathrm{C}$. An IPCC Special Report on the impacts of global warming of $1.5^{\circ} \mathrm{C}$ above pre-industrial levels and related global greenhouse gas emission pathways, in the context of strengthening the global response to the threat of climate change, sustainable development, and efforts to eradicate poverty, eds V. Masson-Delmotte, P. Zhai, H.-O. Pörtner, D. Roberts, J. Skea, P. R. Shukla, et al. (Geneva: World Meteorological Organization Technical Document).

Hu, S., Ding, Y., and Zhu, C. (2020). Sensitivity and responses of chloroplasts to heat stress in plants. Front. Plant Sci. 11:375. doi: 10.3389/fpls.2020.00375

Hughes, T. P., Kerry, J. T., Baird, A. H., Connolly, S. R., Chase, T. J., Dietzel, A., et al. (2019). Global warming impairs stock-recruitment dynamics of corals. Nature 568, 387-390. doi: 10.1038/s41586-019-1081-y

Hughes, T. P., Kerry, J. T., Baird, A. H., Connolly, S. R., Dietzel, A., Eakin, C. M., et al. (2018). Global warming transforms coral reef assemblages. Nature 556, 492-496. doi: 10.1038/s41586-018-0041-2

Innis, T., Allen-Waller, L., Brown, K. T., Sparagon, W., Carlson, C., Kruse, E., et al. (2021). Marine heatwaves depress metabolic activity and impair cellular acidbase homeostasis in reef-building corals regardless of bleaching susceptibility. Glob. Chang. Biol. 27, 2728-2743. doi: 10.1111/gcb.15622

Jokiel, P. L., and Guinther, E. B. (1978). Effects of temperature on reproduction in the hermatypic coral Pocillopora damicornis. Bull. Mar. Sci. 28, 786-789.

Jurriaans, S., and Hoogenboom, M. (2020). Seasonal acclimation of thermal performance in two species of reef-building corals. Mar. Ecol. Prog. Ser. 635, 55-70. doi: 10.3354/meps 13203

Kambey, C. S. B., Kang, J. W., and Chung, I. K. (2020). Impact of temperature, low $\mathrm{pH}$ and $\mathrm{NH} 4+$ enrichment on ecophysiological responses of a green tide species Ulva australis Areschoug. Ocean Sci. J. 55, 115-127. doi: 10.1007/s12601-0200005-y

Keng, F. S.-L., Phang, S.-M., Abd Rahman, N., Yeong, H.-Y., Malin, G., Leedham Elvidge, E., et al. (2021). Halocarbon emissions by selected tropical seaweeds exposed to different temperatures. Phytochemistry 190:112869. doi: 10.1016/j. phytochem.2021.112869

Kilminster, K., McMahon, K., Waycott, M., Kendrick, G. A., Scanes, P., McKenzie, L., et al. (2015). Unravelling complexity in seagrass systems for management: Australia as a microcosm. Sci. Total Environ. 534, 97-109. doi: 10.1016/j. scitotenv.2015.04.061

Kong, E., Ow, Y. X., Lai, S., Yaakub, S. M., and Todd, P. (2019). Effects of shading on seagrass morphology and thermal optimal of productivity. Mar. Freshw. Res. 71, 913-921. doi: 10.1071/MF19173

Kram, S. L., Price, N. N., Donham, E. M., Johnson, M. D., Kelly, E. L. A., Hamilton, S. L., et al. (2016). Variable responses of temperate calcified and 
fleshy macroalgae to elevated pCO2 and warming. ICES J. Mar. Sci. 73, 693-703. doi: 10.1093/icesjms/fsv168

Krause-Jensen, D., and Duarte, C. M. (2016). Substantial role of macroalgae in marine carbon sequestration. Nat. Geosci. 9, 737-742. doi: 10.1038/ngeo2790

Levas, S. J., Grottoli, A. G., Hughes, A., Osburn, C. L., and Matsui, Y. (2013). Physiological and biogeochemical traits of bleaching and recovery in the mounding species of coral Porites lobata: implications for resilience in mounding corals. PLoS One 8:e63267. doi: 10.1371/journal.pone.0063267

Lin, Y.-J., Rabaoui, L., Basali, A. U., Lopez, M., Lindo, R., Krishnakumar, P. K., et al. (2021). Long-term ecological changes in fishes and macro-invertebrates in the world's warmest coral reefs. Sci. Total Environ. 750:142254. doi: 10.1016/j. scitotenv.2020.142254

Madeira, C., Mendonça, V., Leal, M. C., Flores, A. A. V., Cabral, H. N., Diniz, M. S., et al. (2018). Environmental health assessment of warming coastal ecosystems in the tropics-application of integrative physiological indices. Sci. Total Environ. 643, 28-39. doi: 10.1016/j.scitotenv.2018.06.152

Marín-Guirao, L., Entrambasaguas, L., Ruiz, J. M., and Procaccini, G. (2019). Heat-stress induced flowering can be a potential adaptive response to ocean warming for the iconic seagrass Posidonia oceanica. Mol. Ecol. 28, 2486-2501. doi: $10.1111 / \mathrm{mec} .15089$

Marques, J. A., Abrantes, D. P., Marangoni, L. F. B., and Bianchini, A. (2020). Ecotoxicological responses of a reef calcifier exposed to copper, acidification and warming: a multiple biomarker approach. Environ. Pollut. 257:113572. doi: 10.1016/j.envpol.2019.113572

Mayakun, J. (2019). Spatial variation in early patterns of algal recruitment in a tropical intertidal community. Songklanakarin J. Sci. Technol. 41, 254-489. doi: 10.14456/SJST-PSU.2019.60

Mayfield, A. B., Fan, T.-Y., and Chen, C.-S. (2013). Physiological acclimation to elevated temperature in a reef-building coral from an upwelling environment. Coral Reefs 32, 909-921. doi: 10.1007/s00338-013-1067-4

McClanahan, T. (2017). Changes in coral sensitivity to thermal anomalies. Mar. Ecol. Prog. Ser. 570, 71-85. doi: 10.3354/meps12150

Moreno-Marín, F., Brun, F. G., and Pedersen, M. F. (2018). Additive response to multiple environmental stressors in the seagrass Zostera marina L. Limnol. Oceanogr. 63, 1528-1544. doi: 10.1002/lno.10789

Ng, C. S. L., Lim, J. X., Sam, S. Q., Kikuzawa, Y. P., Toh, T. C., Wee, T. W., et al. (2019). Variability in skeletal bulk densities of common hard corals in Southeast Asia. Coral Reefs 38, 1133-1143. doi: 10.1007/s00338-019-01852-2

Nguyen, H. M., Ralph, P. J., Marín-Guirao, L., Pernice, M., and Procaccini, G. (2021). Seagrasses in an era of ocean warming: a review. Biol. Rev. Camb. Philos. Soc. 96, 2009-2030. doi: 10.1111/brv.12736

O’Brien, K. R., Waycott, M., Maxwell, P., Kendrick, G. A., Udy, J. W., Ferguson, A. J. P., et al. (2018). Seagrass ecosystem trajectory depends on the relative timescales of resistance, recovery and disturbance. Mar. Pollut. Bull. 134, 166-176. doi: 10.1016/j.marpolbul.2017.09.006

Ong, G. H. M., Lai, S., Yaakub, S. M., and Todd, P. (2020). Depauperate seed banks in urban tropical seagrass meadows. Mar. Freshw. Res. 71:935. doi: 10.1071/ MF19204

Palumbi, S. R., Barshis, D. J., Traylor-Knowles, N., and Bay, R. A. (2014). Mechanisms of reef coral resistance to future climate change. Science 344, 895-898. doi: 10.1126/science. 1251336

Pedersen, O., Colmer, T. D., Borum, J., Zavala-Perez, A., and Kendrick, G. A. (2016). Heat stress of two tropical seagrass species during low tides-impact on underwater net photosynthesis, dark respiration and diel in situ internal aeration. New Phytol. 210, 1207-1218. doi: 10.1111/nph.13900

Phandee, S., and Buapet, P. (2018). Photosynthetic and antioxidant responses of the tropical intertidal seagrasses Halophila ovalis and Thalassia hemprichii to moderate and high irradiances. Bot. Mar. 61, 247-256. doi: 10.1515/bot-20170084

Phongsuwan, N., and Chansang, H. (2012). Repeated coral bleaching in the Andaman Sea, Thailand, during the last two decades. Phuket Mar. Biol. Center Res. Bull. 71, 19-41.

Pierrot, D., Lewis, E., and Wallace, D. W. R. (2006). MS Excel Program Developed for $\mathrm{CO} 2$ System Calculations. Oak Ridge, TN: Dioxide Information Analysis Center, Oak Ridge National Laboratory, U.S. Department of Energy.

Platt, T., Gallegos, C. L., and Harrison, W. G. (1980). Photoinhibition of photosynthesis in natural assemblages of marine phytoplankton. J. Mar. Res. $38,687-701$
Poquita-Du, R. C., Goh, Y. L., Huang, D., Chou, L. M., and Todd, P. A. (2020). Gene expression and photophysiological changes in Pocillopora acuta coral holobiont following heat stress and recovery. Microorganisms 8:1227. doi: 10. 3390/microorganisms8081227

Porra, R. J. (2002). The chequered history of the development and use of simultaneous equations for the accurate determination of chlorophylls a and b. Photosynth. Res. 73, 149-156. doi: 10.1023/A:1020470224740

Pratchett, M. S., McCowan, D., Maynard, J. A., and Heron, S. F. (2013). Changes in bleaching susceptibility among corals subject to ocean warming and recurrent bleaching in Moorea, French Polynesia. PLoS One 8:e70443. doi: 10.1371/ journal.pone.0070443

Putchim, L., Phongsuwan, N., Yaemarunpattana, C., Thongtham, N., and Richter, C. (2017). Long-term changes in the susceptibility of corals to thermal stress around Phuket, Thailand. PeerJ Preprints 5:e2979v1. doi: 10.7287/peerj. preprints.2979v1

Rasmusson, L. M., Buapet, P., George, R., Gullström, M., Gunnarsson, P. C. B., and Björk, M. (2020). Effects of temperature and hypoxia on respiration, photorespiration, and photosynthesis of seagrass leaves from contrasting temperature regimes. ICES J. Mar. Sci. 77, 2056-2065. doi: 10.1093/icesjms/ fsaa093

Rasmusson, L. M., Nualla-ong, A., Wutiruk, T., Björk, M., Gullström, M., and Buapet, P. (2021). Sensitivity of photosynthesis to warming in two similar species of the aquatic angiosperm Ruppia from tropical and temperate habitats. Sustainability 13:9433. doi: 10.3390/su13169433

Ritchie, R. J. (2006). Consistent sets of spectrophotometric chlorophyll equations for acetone, methanol and ethanol solvents. Photosynth. Res. 89, 27-41. doi: 10.1007/s11120-006-9065-9

Robison, J. D., and Warner, M. E. (2006). Differential impacts of photoacclimation and thermal stress on the photobiology of four different phylotypes of Symbiodinium (Pyrrhophyta). J. Phycol. 42, 568-579. doi: 10.1111/j.1529-8817. 2006.00232.x

Román, M., Román, S., Vázquez, E., Troncoso, J., and Olabarria, C. (2020). Heatwaves during low tide are critical for the physiological performance of intertidal macroalgae under global warming scenarios. Sci. Rep. 10:21408. doi: 10.1038/s41598-020-78526-5

Roth, F., Rädecker, N., Carvalho, S., Duarte, C. M., Saderne, V., Anton, A., et al. (2021). High summer temperatures amplify functional differences between coral- and algae-dominated reef communities. Ecology 102:e03226. doi: 10. $1002 /$ ecy. 3226

Savva, I., Bennett, S., Roca, G., Jordà, G., and Marbà, N. (2018). Thermal tolerance of Mediterranean marine macrophytes: vulnerability to global warming. Ecol. Evol. 8, 12032-12043. doi: 10.1002/ece3.4663

Scheufen, T., Krämer, W. E., Iglesias-Prieto, R., and Enríquez, S. (2017). Seasonal variation modulates coral sensibility to heat-stress and explains annual changes in coral productivity. Sci. Rep. 7:4937. doi: 10.1038/s41598-017-04927-8

Schubert, N., Colombo-Pallota, M. F., and Enríquez, S. (2015). Leaf and canopy scale characterization of the photoprotective response to high-light stress of the seagrass Thalassia testudinum. Limnol. Oceanogr. 60, 286-302. doi: 10.1002/lno. 10024

Short, F. T., and Duarte, C. M. (2001). "Methods for the measurement of seagrass growth and production," in Global Seagrass Research Methods, eds F. T. Short and R. G. Coles (Amsterdam: Elsevier), 155-182. doi: 10.1016/B978044450891-1/50009-8

Sinutok, S., Hill, R., Doblin, M. A., Kühl, M., and Ralph, P. J. (2012). Microenvironmental changes support evidence of photosynthesis and calcification inhibition in Halimeda under ocean acidification and warming. Coral Reefs 31, 1201-1213. doi: 10.1007/s00338-0120952-6

Sinutok, S., Hill, R., Doblin, M. A., Wuhrer, R., and Ralph, P. J. (2011). Warmer more acidic conditions cause decreased productivity and calcification in subtropical coral reef sediment-dwelling calcifiers. Limnol. Oceanogr. 56, 1200 1212. doi: 10.4319/lo.2011.56.4.1200

Skirving, W. J., Heron, S. F., Marsh, B. L., Liu, G., De La Cour, J. L., Geiger, E. F., et al. (2019). The relentless march of mass coral bleaching: a global perspective of changing heat stress. Coral Reefs 38, 547-557. doi: 10.1007/s00338-01901799-4

Smale, D. A., Wernberg, T., Oliver, E. C. J., Thomsen, M., Harvey, B. P., Straub, S. C., et al. (2019). Marine heatwaves threaten global biodiversity and the 
provision of ecosystem services. Nat. Clim. Chang. 9, 306-312. doi: 10.1038/ s41558-019-0412-1

Strydom, S., Murray, K., Wilson, S., Huntley, B., Rule, M., Heithaus, M., et al. (2020). Too hot to handle: unprecedented seagrass death driven by marine heatwave in a World Heritage Area. Glob. Chang. Biol. 26, 3525-3538. doi: $10.1111 /$ gcb. 15065

Stuart-Smith, R. D., Edgar, G. J., and Bates, A. E. (2017). Thermal limits to the geographic distributions of shallow-water marine species. Nat. Ecol. Evol. 1, 1846-1852. doi: 10.1038/s41559-017-0353-x

Sutthacheep, M., Saenghaisuk, C., Pengsakun, S., Donsomjit, W., and Yeemin, T. (2013a). Quantitative studies on the 2010 mass coral bleaching event in Thai waters. Galaxea 15, 379-390. doi: 10.3755/galaxea.15.379

Sutthacheep, M., Yucharoen, M., Klinthong, W., Pengsakun, S., Sangmanee, K., and Yeemin, T. (2013b). Impacts of the 1998 and 2010 mass coral bleaching events on the Western Gulf of Thailand. Deep Sea Res. 2 Top. Stud. Oceanogr. 96, 25-31. doi: 10.1016/j.dsr2.2013.04.018

Tanzil, J. T. I., Brown, B. E., Tudhope, A. W., and Dunne, R. P. (2009). Decline in skeletal growth of the coral Porites lutea from the Andaman Sea, South Thailand between 1984 and 2005. Coral Reefs 28, 519-528. doi: 10.1007/s00338-0080457-5

Terada, R., Vo, T. D., Nishihara, G. N., Shioya, K., Shimada, S., and Kawaguchi, S. (2016). The effect of irradiance and temperature on the photosynthesis and growth of a cultivated red alga Kappaphycus alvarezii (Solieriaceae) from Vietnam, based on in situ and in vitro measurements. J. Appl. Phycol. 28, 457-467. doi: 10.1007/s10811-015-0557-x

Tremblay, P., Gori, A., Maguer, J. F., Hoogenboom, M., and Ferrier-Pagès, C. (2016). Heterotrophy promotes the re-establishment of photosynthate translocation in a symbiotic coral after heat stress. Sci. Rep. 6:38112. doi: 10 . 1038/srep38112

van Oppen, M. J. H., and Oakeshott, J. G. (2020). A breakthrough in understanding the molecular basis of coral heat tolerance. Proc. Natl. Acad. Sci. U.S.A. 117, 28546-28548. doi: 10.1073/pnas.2020201117

Veal, C. J., Carmi, M., Fine, M., and Hoegh-Guldberg, O. (2010). Increasing the accuracy of surface area estimation using single wax dipping of coral fragments. Coral Reefs 29, 893-897. doi: 10.1007/s00338-010-0647-9

Vinagre, C., Dias, M., Cereja, R., Abreu-Afonso, F., Flores, A. A. V., and Mendonça, V. (2019). Upper thermal limits and warming safety margins of coastal marine species-indicator baseline for future reference. Ecol. Indic. 102, 644-649. doi: 10.1016/j.ecolind.2019.03.030

Wasim, M. d., Pandey, A. C., Kumar, A., and Dwivedi, C. S. (2021). Spatiotemporal mapping to investigate coral bleaching in Andaman and Nicobar Islands, India using geoinformatics. J. Indian Soc. Remote Sens. 49, 1879-1894. doi: 10.1007/s12524-021-01345-2

Waycott, M., Duarte, C. M., Carruthers, T. J. B., Orth, R. J., Dennison, W. C., Olyarnik, S., et al. (2009). Accelerating loss of seagrasses across the globe threatens coastal ecosystems. Proc. Natl. Acad. Sci. U.S.A. 106, 12377-12381. doi: $10.1073 /$ pnas.0905620106

Wernberg, T., Krumhansl, K., Filbee-Dexter, K., and Pedersen, M. F. (2019). "Status and trends for the world's kelp forests," in World Seas: An Environmental Evaluation, ed. C. Sheppard (Amsterdam: Elsevier), 57-78. doi: 10.1016/B9780-12-805052-1.00003-6

Wham, D. C., Ning, G., and LaJeunesse, T. C. (2017). Symbiodinium glynnii sp. nov., a species of stress-tolerant symbiotic dinoflagellates from pocilloporid and montiporid corals in the Pacific Ocean. Phycologia 56, 396-409. doi: 10.2216/ 16-86.1
Wichachucherd, B., Liddle, L. B., and Prathep, A. (2010). Population structure, recruitment, and succession of the brown alga, Padina boryana Thivy (Dictyotales, Heterokontophyta), at an exposed shore of Sirinart National Park and a sheltered area of Tang Khen Bay, Phuket Province, Thailand. Aquat. Bot. 92, 93-98. doi: 10.1016/j.aquabot.2009.10.008

Wuthirak, T., Kongnual, R., and Buapet, P. (2016). Desiccation tolerance and underlying mechanisms for the recovery of the photosynthetic efficiency in the tropical intertidal seagrasses Halophila ovalis and Thalassia hemprichii. Bot. Mar. 59, 387-396. doi: 10.1515/bot-2016-0052

Xu, H., Feng, B., Xie, M., Ren, Y., Xia, J., Zhang, Y., et al. (2020). Physiological characteristics and environment adaptability of reef-building corals at the Wuzhizhou Island of South China Sea. Front. Physiol. 11:390. doi: 10.3389/ fphys.2020.00390

Xu, S., Yu, K., Tao, S., Wu, C.-C., Wang, Y., Jiang, W., et al. (2018). Evidence for the thermal bleaching of Porites corals from $\mathrm{m} 4.0 \mathrm{ka}$ B.P. in the northern South China Sea. J. Geophys. Res. Biogeosci. 123, 79-94. doi: 10.1002/2017JG00 4091

Yeemin, T., Saenghaisuk, C., Sutthacheep, M., Pengsakun, S., Klinthong, W., and Saengmanee, K. (2009). Conditions of coral communities in the Gulf of Thailand: a decade after the 1998 severe bleaching event. Galaxea 11, 207-217. doi: $10.3755 /$ galaxea.11.207

Zhang, T., Qu, Y., Zhang, Q., Tang, J., Cao, R., Dong, Z., et al. (2021). Risks to the stability of coral reefs in the South China Sea: an integrated biomarker approach to assess the physiological responses of Trochus niloticus to ocean acidification and warming. Sci. Total Environ. 782:146876. doi: 10.1016/j.scitotenv.2021. 146876

Zhang, Y., He, P., Li, H., Li, G., Liu, J., Jiao, F., et al. (2019). Ulva prolifera greentide outbreaks and their environmental impact in the Yellow Sea, China. Natl. Sci. Rev. 6, 825-838. doi: 10.1093/nsr/nwz026

Zhang, Y.-P., Shen, C., Li, F., Shen, Y.-C., and Liu, L. (2018). Ultrastructural changes of endosymbiotic Symbiodinium of Galaxea astreata under thermal stress and after short time recovery process. J. Mar. Sci. Res. Dev. 8:6. doi: 10.4172/2155-9910.1000262

Zhao, M., Zhang, H., Zhong, Y., Jiang, D., Liu, G., Yan, H., et al. (2019). The status of coral reefs and its importance for coastal protection: a case study of northeastern Hainan Island, South China Sea. Sustainability 11:4354. doi: $10.3390 /$ su11164354

Conflict of Interest: The authors declare that the research was conducted in the absence of any commercial or financial relationships that could be construed as a potential conflict of interest.

Publisher's Note: All claims expressed in this article are solely those of the authors and do not necessarily represent those of their affiliated organizations, or those of the publisher, the editors and the reviewers. Any product that may be evaluated in this article, or claim that may be made by its manufacturer, is not guaranteed or endorsed by the publisher.

Copyright (c) 2021 Yucharoen, Sinutok, Chotikarn and Buapet. This is an openaccess article distributed under the terms of the Creative Commons Attribution License (CC BY). The use, distribution or reproduction in other forums is permitted, provided the original author(s) and the copyright owner(s) are credited and that the original publication in this journal is cited, in accordance with accepted academic practice. No use, distribution or reproduction is permitted which does not comply with these terms. 